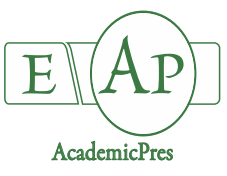

Sârbu A et al. (2020)

Notulae Botanicae Horti Agrobotanici Cluj-Napoca 48(1):456-479

DOI: $10.15835 /$ nbha 48111756

Research Article

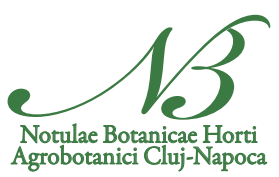

\title{
The potential sensitivity to climate change of selected endangered and important Natura 2000 Habitats and plants from Bucegi Natural Park, Romania
}

\author{
Anca SÂRBU ${ }^{1}$, Georg A. JANAUER ${ }^{2 *}$, Norbert EXLER ${ }^{2}$, Ion SÂRBU ${ }^{3}$, \\ Paulina ANASTASIU ${ }^{1,4}$
}

\author{
${ }^{1}$ University of Bucharest, Faculty of Biology, Department of Botany-Microbiology, 1-3 Intrarea Portocalelor, 060101 Bucharest, \\ Romania;anchusa24@yahoo.com;paulina.anastasiu@bio.unibuc.ro \\ ${ }^{2}$ University of Vienna, Department of Limnology and Biological Oceanography, 14 Althanstraße, 1090 Vienna, \\ Austria; georg.janauer@univie.ac.at ("correspondingauthor);norbert@exler.at \\ ${ }^{3}$ University “Al. I. Cuza”, Faculty of Biology, Department of Botany, 11 Bulevardul Carol I, 700506 Iaşi, \\ Romania;ionsarbu@hotmail.com \\ ${ }^{4}$ University of Bucharest, Botanic Garden "D. Brandza", Şos. Cotroceni 32, Bucharest, Romania
}

\begin{abstract}
This study was carried out in the Bucegi Natural Park, a protected area of the Romanian Carpathians. It aims at documenting the potential sensitivity of six widespread Natura 2000 habitat types and of all plants with conservative value (200 taxa) in the mountain area, to the changes in temperature and humidity, predicted for this century. Regional expert knowledge and environmental indicator values were considered in assessing the potential habitat's sensitivity. The results support the evidence that sensitivity to temperature may be potentially higher for habitats at alpine and subalpine levels (bushes and grasslands) and medium for forest habitats. Sensitivity to moisture was detected as potentially high for forest habitats and as medium for bushes and grasslands at high mountain elevation. Microthermophilic plants have shown a greater share (76-79\%) in alpine and subalpine communities, and the hydrophilic plants (86-96\%) in forest communities. About $80 \%$ of plants of conservation value (microthermophilic or hydrophilic plants) may be potentially sensitive to predicted warming and drought and $44 \%$ of them (microthermophilic and hydrophilic plants) to the changes of both parameters. Climate scenarios (2011-2100) and sensitivity maps (Sat - image interpretation with GIS for the whole mountain area) are included.
\end{abstract}

Keywords: climate scenarios; Natura 2000 habitats; sensitivity maps; protected plants; nature conservation

\section{Introduction}

In recent years, attention has focused on climate change as a threat to natural heritage (ecosystems, habitats and species) assigned to different categories of protected areas (IPCC 2007). Special attention was addressed to the possible impact of climate change on plants and vegetation, as one of their fundamentals of life. The studies developed by Thuiller et al. (2005) for 1,350 European plant species (about 10\% of European 
Flora), show that more than half of them could be affected by climatic disturbance by 2080 . Special attention needs alpine and arctic ecosystems, that may be particularly vulnerable to climate change (Klanderud and Totland, 2005). Information about the future of plants and habitats in protected areas already raises such concerns (Andrade et al., 2010; EEA, 2012). Many effects addressing Natura 2000 habitats (protected under Habitat Directive of the European Union) were already observed (Campbell et al., 2009; Erschbamer et al., 2009), which affected protected plants and habitats in different ways and with different magnitude (Andrade et al., 2010; Sârbu et al., 2014). Some studies (Araújo et al., 2011) even anticipate a possible reduction of plant and animal diversity in protected areas of Europe by more than $50 \%$ towards the end of this century, due to unsuitable environmental conditions. Significant changes are expected for the European plant communities: in Northern Europe 35\% of the species may be new until 2100 and in Southern Europe up to 25\% of the species have chances to disappear (Alkemade et al., 2011). The Inouye (2019) estimates for the mountains of Europe highlight that $36-55 \%$ of the alpine species, $31-51 \%$ of subalpine species and $19-46 \%$ of the montane species, will lose more than $80 \%$ of their habitats by 2070-2100. For the North American Flora, Zhang et al. (2016) underlined that about 2,000 species may lose more than $80 \%$ of their habitats due to climate change impact.

It is increasingly evident that climate change will come, in the near or not too distant future, a strong driver of changes in habitat conditions and species composition. This is regarded a serious long-term threat for many mountain areas in Europe. Recent studies (Engler et al., 2011; Dullinger et al., 2012) on higher plants species in high mountain areas of Europe warn that up to the end of $21^{\text {st }}$ Century, a significant loss of habitats will be recorded for plants living at high altitudes. It is expected that up to $50 \%$ or $55 \%$ of these plants may lose more than $80 \%$ of their habitats inhabited today, due to emerging climatic disturbance. Despite the fact that mountain areas in general are sensitive to climatic impact, their vulnerability is certainly different and depends significantly on the amplitude of the shifts in climatic conditions and the response of the affected species as there are: genetic adaptation, biological migration and species extinction (Theurillat and Guisan, 2001; Beniston, 2003; EEA, 2012). In case of a high increase in the mean air temperature, profound changes may be expected in the higher mountain systems of Europe, such as the Alps (Theurillat et al., 1998) and the Carpathians (Sârbu et al., 2014). Changes in composition and distribution of plants, e.g. expressed by altitudinal shift (Pauli et al., 1996; Gottfried et al., 1999; Walther et al., 2005; Kullman, 2007; Erschbamer et al., 2009), will result in phenological modifications which will affect the life cycle of woody and herbaceous plants (Bazzaz, 1996; Cleland et al., 2006; Vitasse et al., 2011), will threat plant reproduction and growth (Lapenis et al., 2005; Gray et al., 2016), will support the spread of invasive plants (Hellmann et al., 2008; EEA, 2012) and will increase the risk of extinction of indicator species, rare and endemic plants (Lesica and McCune, 2004; Schöb et al., 2008; Sârbu et al., 2014). All these processes can induce a pronounced decrease of conservation value of Natura 2000 habitats, located at high elevation.

There are many factors that influence plants responses to climate change (Thuiller et al., 2005; Grimm et al., 2013; Sârbu et al., 2014; Matteodo et al., 2016), including also their ecological preferences and the magnitude of variation, that plants can withstand. Plants have specific requirements in terms of their environment, which are important for their survival and spread. The knowledge of plant preferences towards temperature and humidity, can offer information on the potential trends of change in functional and taxonomic groups of the communities, as direct consequences of heat and drought.

The present contribution represents a case study, addressed to the whole Bucegi Natural Park, a Carpathian protected area in Romania and part of the Natura 2000 Bucegi site. Six representative and very widespread types of Natura 2000 habitats from Bucegi Natural Park and all the plants with conservation value, from the entire Natura 2000 site Bucegi area (200 taxa) were considered. The following issues are discussed:

i) which are the trends of the temperature and humidity regime in Bucegi Natural Park, in this century?

ii) which plants can be potentially sensitive to the predicted changes in temperature and humidity?

iii) how sensitive can be the selected habitats, to predict climatic constraints? 


\section{Materials and Methods}

\section{Study area}

Bucegi Natural Park (32,497.6 ha) is located in the South-Eastern part of the Romanian Carpathians, in the Alpine biogeographical region, and is a major component of the Natura 2000 Site Bucegi (Figure 1). It is a cold and humid mountain zone which displays a difference in altitude between $806 \mathrm{~m}$ and $2507 \mathrm{~m}$. The winter starts early, with a long-lasting cover of snow across most of the alpine plateau of Bucegi. This mountainous region hosts a diversity of habitats from alpine and subalpine grasslands to tall forbs habitats, shrubs, rocks and screes habitats, chasmophyte vegetation on calcareous rocks, peat bags, forests (deciduous, coniferous and mixed), rivers and lakes. The flora is rich in higher plants ( 1183 cormophytes, about $30 \%$ of the Romanian flora), with numerous endemic and rare elements, some of them protected at national, European or global level. Other groups such as mosses (259 taxa) and lichens (485 taxa) are also well represented (APNB, 2011). From the existing habitat types, 24 are nominated for protection and conservation in the Habitat Directive. They belong to the following categories: rocks, bushes, swamps, grasslands, hydrophilic vegetation and deciduous, coniferous and mixed forests (APNB, 2011). Forests, grasslands and shrubs habitats are widespread and have a large share in the vegetation of Bucegi Natural Park (APNB, 2011).

\section{Assessment of habitats}

Six selected habitat types of characteristic and widespread categories in Bucegi (forests, grasslands and bushes) were considered in this study (Table 1). The threatened habitats, with priority for conservation according to Habitat Directive, are marked with an asterisk $\left(^{*}\right)$.

Two approaches were used for the sensitivity of habitats assessment: one was focused on regional expert knowledge and the other incorporated the information about the ecological envelope of the habitats, by assessing the current plant community composition (Wagner-Lücker, 2012; Wagner-Lücker et al., 2014; Figure 2).

Table 1. Natura 2000 habitats in the study area (* - globally threatened): Natura 2000 habitat code, class definition, altitude and climate (Mountford et al., 2008)

\begin{tabular}{|c|l|c|c|c|}
\hline $\begin{array}{c}\text { Natura } \\
2000 \\
\text { habitat } \\
\text { code }\end{array}$ & \multicolumn{1}{|c|}{ Class definition } & $\begin{array}{c}\text { Average } \\
(\mathrm{m})\end{array}$ & $\begin{array}{c}\text { Temperature } \\
\text { (annual average, } \\
\left.{ }^{\circ} \mathrm{C}\right)\end{array}$ & $\begin{array}{c}\text { Rainfall } \\
(\mathrm{mm} / \text { year })\end{array}$ \\
\hline $4070^{*}$ & Bushes with Pinus mugo and Rhododendron myrtifolium & $1400-2000$ & $+2.2--0.2$ & $1250-1425$ \\
\hline 6150 & Siliceous alpine and boreal grasslands & $1550-2500$ & $+3.0--2.5$ & $1100-1450$ \\
\hline 6230 & $\begin{array}{l}\text { Species-rich Nardus grasslands on siliceous substrates in } \\
\text { mountain areas (and submountain areas in Continental } \\
\text { Europe) }\end{array}$ & $800-2070$ & $+6.0--1.5$ & $800-1400$ \\
\hline 9110 & Luzulo-Fagetum beech forests & $600-1350$ & $+3.0-+8.0$ & $700-1300$ \\
\hline 91 V0 & Dacian beech forests (Symphyto-Fagion) & $500-1450$ & $+3.0-+8.0$ & $750-1200$ \\
\hline 9410 & $\begin{array}{l}\text { Acidophilous Picea forests on the montane to alpine } \\
\text { levels (Vaccinio-Piceetea) }\end{array}$ & $1000-1850$ & $+1.5-+5.0$ & $900-1400$ \\
\hline
\end{tabular}




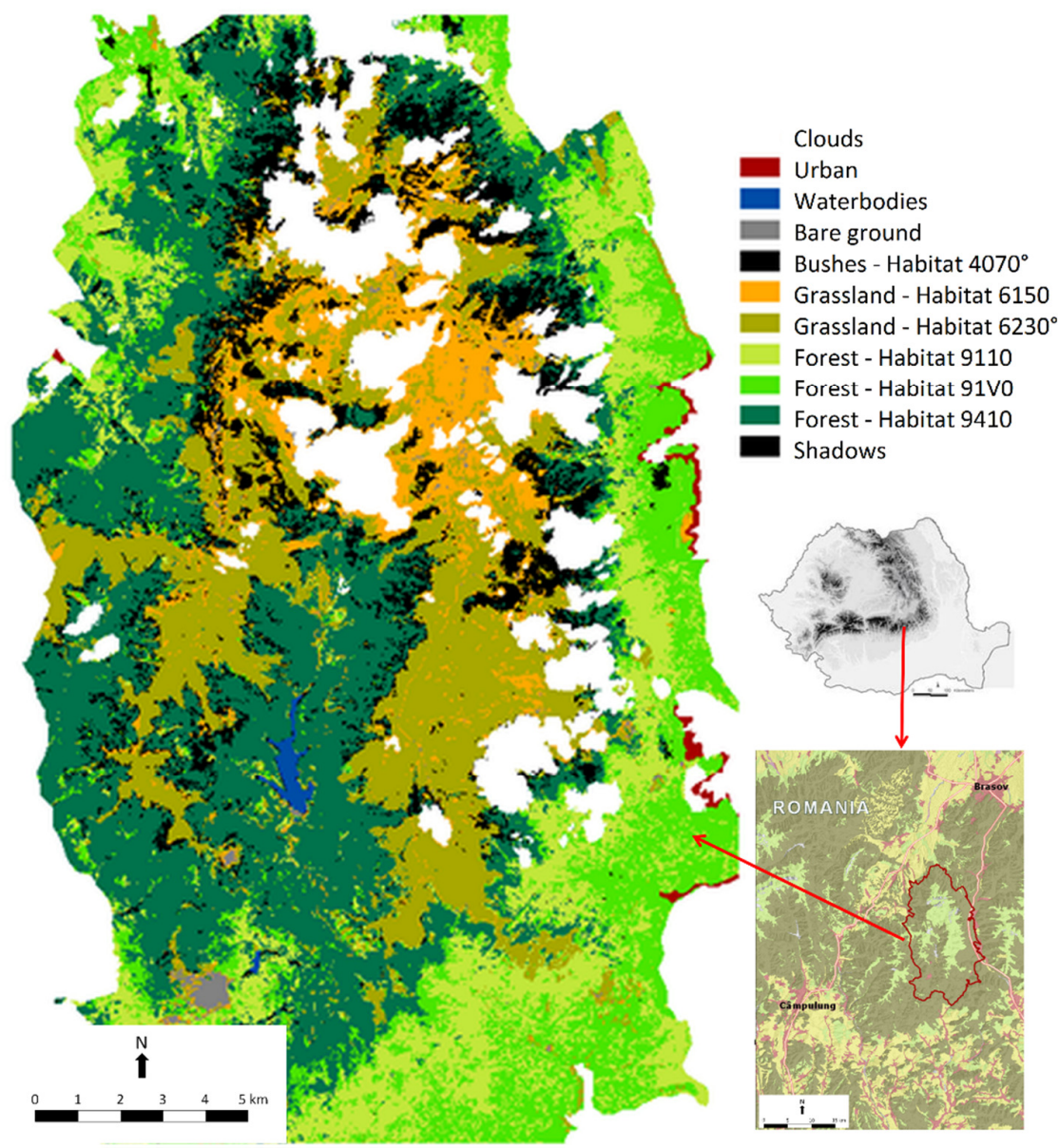

Figure 1. Location and outline of Bucegi Natural Park, Romania (right) (Basic geodata: NUTS database@EuroGeographics 2006, Investigation area: Project partners 20101 Map: Neubert, Puschel, Witschas 2010), and distribution of the selected Natura 2000 habitat types (left) (Map: Wagner, Förster, Schmidt, 2012 - HABIT-CHANGE project). This map contains more than 65000 polygons representing the Habitat Types. Depending on the screen resolution or the print the image may appear spotted

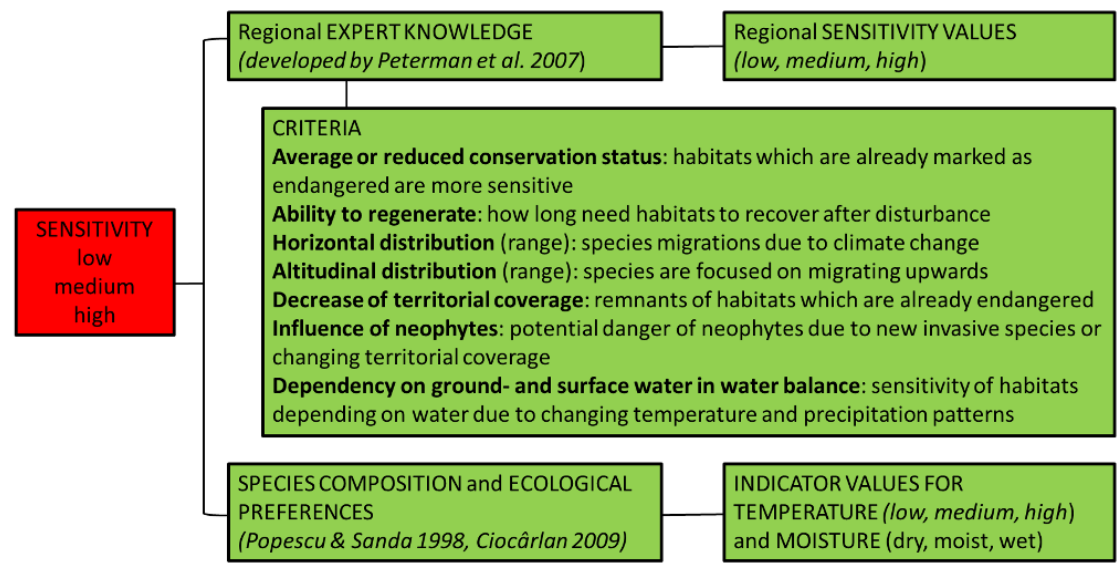

Figure 2. Framework for the habitat's sensitivity assessment (Wagner-Lücker, 2012 - HABIT CHANGE project, outputs 4.3.5. 4.6.1. 4.6.2.) 
The framework for the regional expert knowledge was based on Petermann's approach (Petermann et al., 2007), who evaluated the sensitivity of Natura 2000 habitats in Germany. This assessment procedure was structured into seven sensitivity criteria (Wagner-Lücker $e$ t al., 2014): average or reduced conservation status, ability to regenerate, horizontal distribution, altitudinal distribution, decrease of territorial coverage, influence of neophytes, dependency on ground and surface water (Figure 2). For each habitat type each criterion was classified as: 1-low, 2-medium and 3-high. To describe the overall sensitivity of a habitat type in relation with its biogeographic position, these values were summed and categorized after Petermann et al. (2007) in tree sensitivity categories: 1-low (<14), 2-medium (14-16), 3-high (>16) (Wagner-Lücker et al., 2014).

The variability of the ecological envelope of habitats was assessed using indicator values. These were derived from the characteristic species composition in each habitat. Temperature values (climatic parameter) and moisture values (edaphic parameter) were selected as indicator parameters. Three categories were used for temperature: low (species from high elevation, sustainable under low air temperature), medium (species from midlands, needing average air temperature) and high (species from low elevation, needing higher air temperature). Three categories were used for moisture: dry (species sustaining low soil moisture), moist (species needing average soil moisture) and wet (species needing high soil moisture). Both the indicator values of temperature and moisture were the base for the statistical calculation of the overall indicator value per habitat type. The frequency of the categorized indicator values per habitat type and per biogeographical region was then used in the sensitivity assessment: low, medium and high sensitivity.

To support the habitat type assessment, a detailed field survey was carried out in the vegetation period 2010-2012. Two areas of investigation have been selected from the perimeter of Bucegi Natural Park:

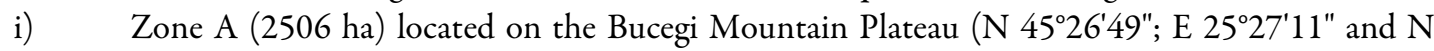
$\left.45^{\circ} 22^{\prime} 50^{\prime \prime} ; \mathrm{E} 25^{\circ} 29^{\prime} 45^{\prime \prime}\right)$, that includes the type of vegetation characteristic of the alpine level.

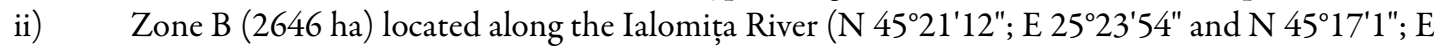
$\left.25^{\circ} 26^{\prime} 29^{\prime \prime}\right)$ that includes wooden vegetation, mostly represented by forests.

Inside the investigation areas, 153 field survey units have been established (Figure 3). 80 referred to the selected habitat types in this study and 46 of them were described in terms of species richness, species abundance-dominance and ecological preferences of species, in relation to the climatic factors such as temperature and humidity. For each type of habitat, a unique taxa list was also developed, that was used to evaluate ecological preferences of plants/habitat type. Identification of the habitat types was carried out in accordance with the following sources: Doniță et al. (2005), Gafta and Mountford (2008), Mountford et al. (2008), Sârbu et al. (2013).

\section{Plants assessment}

Plant assessment has focused on two aspects:

i) knowledge of the ecological preferences for temperature and humidity of the plants in the studied habitat types of Bucegi Natural Park (including plants with conservation value, that live there);

ii) identification of plants with conservation value throughout the entire Natura 2000 site Bucegi and knowledge of their preferences for temperature and humidity.

Scale for moisture and temperature (Popescu and Sanda, 1998; Ciocârlan, 2009; Sârbu et al., 2013) was used in determining ecological preferences of the species included in this study.

The identification of plants with conservation value was realised according to IUCN Red List (Bilz et al., 2011), Habitat Directive annexes (EEC, 1992), Bern Convention (Council of Europe, 1979), CITES (1979), Romanian Red List (Oltean et al., 1994), Romanian Flora (Săvulescu, 1952-1976), Illustrated Flora of Romania: Pteridophyta and Spermatophyta (Ciocârlan, 2009), and the list of the Management Plan of Natural Park Bucegi, Annex 8 (APNB, 2011). The general distribution of plants was assessed following Sârbu et al. (2013). Plant nomenclature is according to The Plant List (2013), Ciocârlan (2009) and Sârbu et al. (2013). 


\section{Climate scenarios}

The studies carried out during the EU-Project 'Habit-Change' focused on Habitat-Types related to the flora present in a sample of 12 habitat types; the Bucegi example was selected as one of these landscape types. These encompassed a variety of countries and landscapes, like National Parks (PL 1, HU 2, AT/HU 1, SI 1), Nature/Natural Parks (RO 1, SI 1, IT 1, UA 1) and Biosphere Reserves (DE 2, RO 1). The Romanian team was partner in this consortium, caring for the Bucegi floristic contents.

For these 12 protected habitat types (i) the observed trends in hydro-climatic conditions over the last century, as well as (ii) the quantification of climate change impacts as boundary conditions, were meticulously determined to show the predicted trends in climate and climate scenarios, which finally produced regional results for each of the 12 protected habitat types. Six of them are included in this publication.

The methodology is explained in detail in section 2.2. (p.6), for the hydrological features, and in section 3.2. (p.39), of the Habit-Change-Project-Report: Climate change impacts as boundary condition and hydrological features (Stagl L., Hattermann, F. 2011. Climate change impacts as boundary conditions + Hydrological features of selected areas. 55pp.). This report is part of the CENTRAL-EUROPE-Program EU: HABIT-CHANGE - Adaptive management of climate-induced changes of habitat diversity in protected areas (2013). Project Number: 2CE168P3. First information is provided under https://www.keep.eu/project/5501/adaptive-management-of-climate-induced-changes-of-habitat-diversity-inprotected-areas. Further information is found at the same LINK (accessed again: 20190425).

Stagl and Hattermann (2011) provided the methodological background behind the graphs in Figure 4, showing the results of the individual climate models, on a monthly basis, for the two time periods, as well as the averaged development of the climatic conditions for each of the protected areas (Table 2).
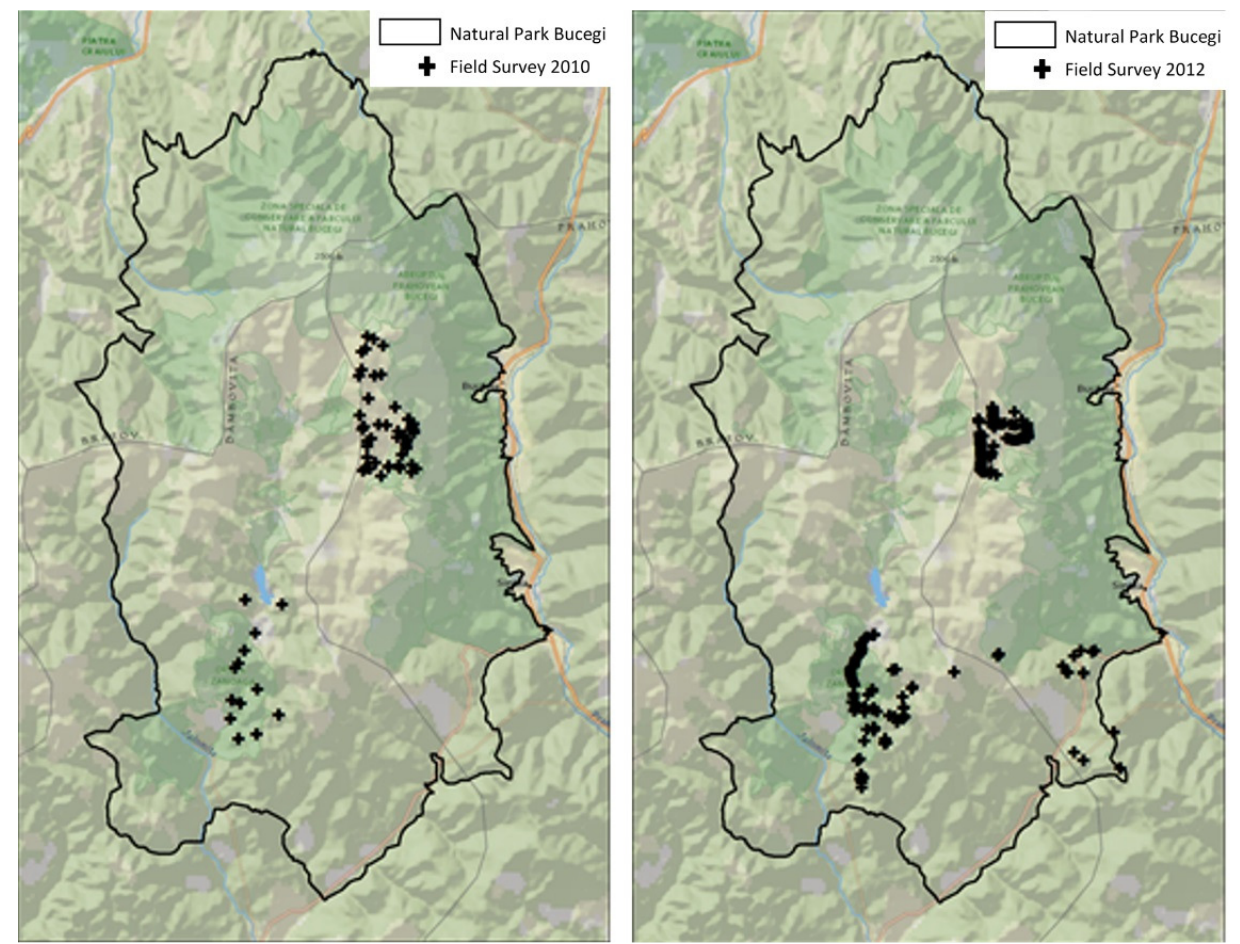

Figure 3. Location of the field surveys in 2010 (left) and 2012 (right) (Wagner-Lücker, 2012 - HABIT CHANGE project, output 4.3.2.) 


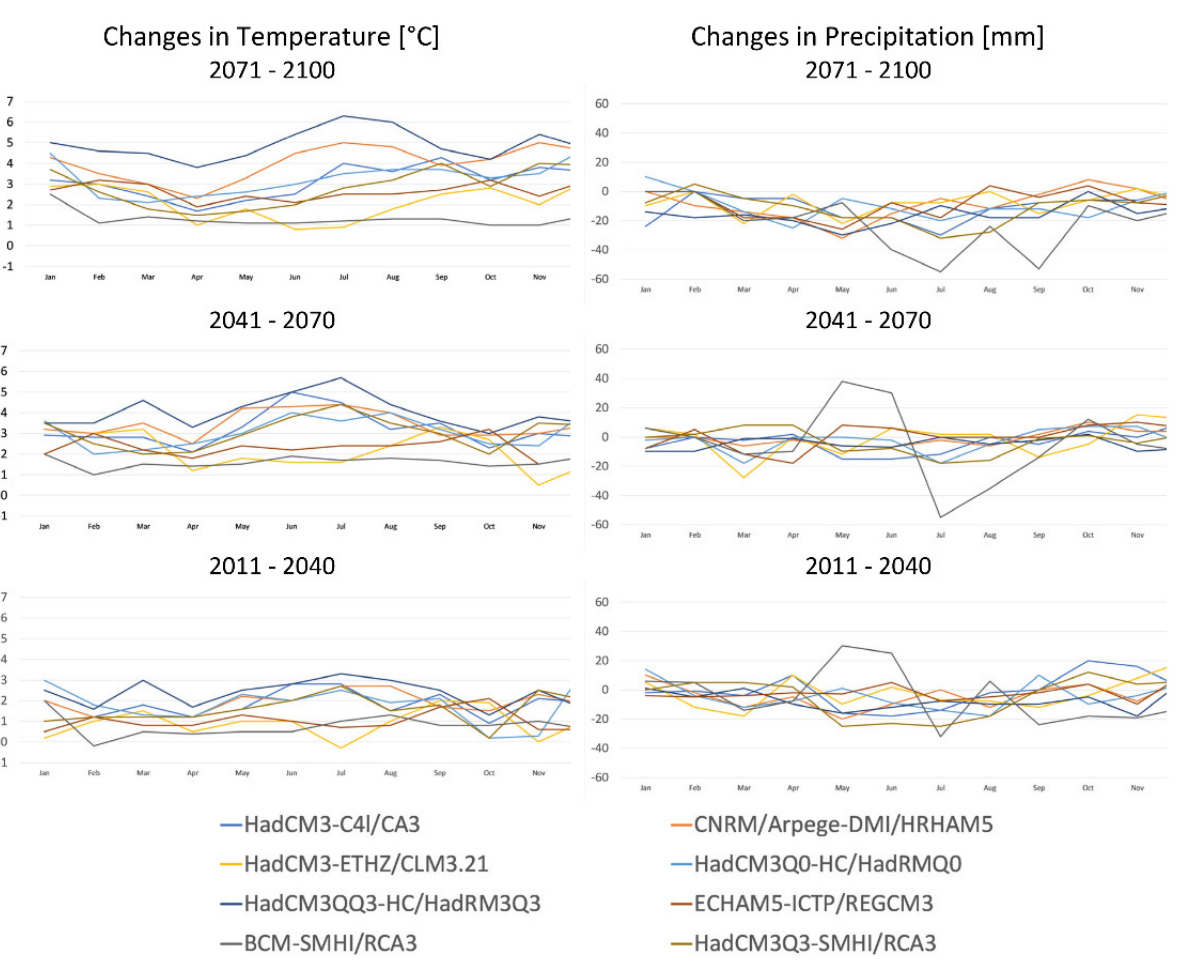

Figure 4. Bucegi Natural Park (Romania): Climate scenarios - Temperature and Precipitation 2011-2100 (source: HABIT-CHANGE project, outputs 3.2.3. and 3.2.7.). The color lines - Climate Models (GCMRCM combinations)

Table 2. Parameters used to provide the essential methodological basis

\begin{tabular}{|c|l|}
\hline Number & \multicolumn{1}{|c|}{ Parameters } \\
\hline 1 & Analysis of a global climate dataset, $0.5 \times 0.5$-degree resolution \\
\hline 2 & $\begin{array}{l}\text { Re-analysed daily climate data, bias-corrected on observed data, bi-linearly interpolated to global } \\
\text { land grid }\end{array}$ \\
\hline 3 & Spatial resolution $~ 50 \mathrm{~km} \times 50 \mathrm{~km}$, for 'virtual climate stations' per grid cell \\
\hline 4 & $\begin{array}{l}\text { Original resolution retained for each of the } 12 \mathrm{HABIT-CHANGE} \mathrm{investigation} \mathrm{areas,} \\
\text { representing an average climate data set for each } 50 \mathrm{~km}^{2} \text { cell area }\end{array}$ \\
\hline 5 & $\begin{array}{l}\text { Observed trends in hydro-climatic conditions cover two periods of 15 years: 1960-1974, 1987- } \\
2001, \text { plotted as long-term average in the same diagram }\end{array}$ \\
\hline
\end{tabular}

For assessing the different alpine habitats across the Bucegi massif remote sensing, in this case highresolution satellite imagery (development level of 2012, spatial resolution: $5 \mathrm{~m}$ ) was used. This work was carried out as part of the HABIT-CHANGE Project, supported by the CENTRAL EUROPE Programme (EU), which can be accessed on:

https://webcache.googleusercontent.com/search?q=cache:yue $7 Y_{-} K k$ AikJ:https://www2.ioer.de/download/ habit-change/HABIT-CHANGE_4_2_3-4_2_4-4_2_5_Remote_Sensing_2013-08-

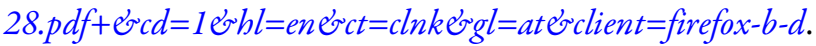

Participants of the University of Bucharest, as well as of the University of Vienna, were co-authoring this part of the above-mentioned project.

Mountain regions like the Bucegi are, at least in part, composed of remote and less accessible areas. Remote sensing methods are capable of acquiring and analysing information on different habitat types, especially when investigating larger areas (Bucegi: approx. $284 \mathrm{~km}^{2}$ ). Remote sensing also provides a basis for 
repeatable investigations. Even though clouds are often present in mountain areas, the interpretation of vegetation types was possible to a great extent, since images of May, July and September 2010 were used for interpretation. Compared with other methods, e.g. ground-based exploration, remote sensing provides an overview on large areas instantly. In addition, this overview allows the determination where future, more detailed research may secure success.

The remote sensing imagery was georeferenced and used multi-temporal images. The Terrain Analysis used the ASTER Global Digital Elevation Model.

During the vegetation periods of 2010 and 2012 field data were collected for the six habitat types (Table $1)$.

Object-based image analysis (OBIA) was used to delineate polygons for the individual habitat-types. For assessing the alpine grassland and forest habitat types digital elevation model was combined with the RapidEye imagery. Due to cloud cover, which was the lowest in the July image, not all field survey units could be used, but the vegetation development was the best during this period. Water bodies were classified by spectral information. University of Bucharest provided military maps from which urban areas were extracted. Visual interpretation was used to delineate cloud cover in the July image. Spectrally evaluated sample points were generated for classification of land cover, and good land cover classes. eCognition Developer 8 software (Trimble; http://www.ecognition.com/document/ecognition-8-datasheet) was used for OBIA. Based on terrain (elevation, slope, aspect) and spectral values polygons of homogenous regions were produced by image segmentation.

The sample points defined the feature space of the different Land Cover Classes, using the Nearest Neighbour Classifier, a supervised classification algorithm of the eCognition software. Thereafter 'Grassland' $\left(6150,6230^{*}\right)$ Bushes $\left(4070^{*}\right)$ and 'Forest' (deciduous 9110, 91V0, coniferous 9410) were divided into habitat types, with field survey points as classification samples.

Two sets of climate scenarios, highlighting trends of the thermic and rainfall regime for the period 20112100, were developed as part of the project HABIT-CHANGE (Figure 4). The diagram displays the monthly average for temperature and precipitation over a year. Coloured lines in the graph show monthly changes, simulated by an ensemble of different GCM (Global Climatic Models)/RCM (Regional Climatic Models) combinations. The grey bands indicate the total range of uncertainty.

Observed trends in hydrological conditions are displayed by two periods of 15 years each (1960-1974 and 1987-2001), taken as reference (HABIT-CHANGE - output 3.2.7. Stagl J. and Hattermann F., Potsdam Institute for Climate impact). For climate scenarios, based on the analysis of different GCM combinations, a reference period of 30 years (between years 1961-1990) was selected (HABIT-CHANGE - output 3.2.3. Stagl $\mathrm{J}$ and Hattermann FF, Potsdam Institute for Climate Impact).

\section{Results}

\section{Climate scenarios}

Climate scenarios, specially developed for the Bucegi Natural Park for the period 2011-2100, forecast a trend of increasing air temperature throughout the year, with emphasis towards the end of this century $(+2.5$ ${ }^{\circ} \mathrm{C}$ increase in the mean annual air temperature). Summer increase is considered more significant especially after 2040 (Figure 4). Trends predicted for precipitation are quite heterogeneous, since the climate scenarios for 2011-2040 did not show a clear change of current conditions in the Bucegi Natural Park. For the periods 2041-2070, and 2071-2100, respectively, a general reduction in rainfall is expected, which will be more significant in the summer period initially (Figure 4) but following the year 2070 water stress will affect almost all periods of the year. 


\section{Habitat sensitivity}

For the six selected habitat types (Natura 2000 Code: 4070*, 6150, 6230*, 9110, 91V0, 9410), two maps of potential sensitivity to temperature and humidity were produced. These showed a potential of medium to high sensitivity to changes in air temperature (Figure 5) and edaphic humidity (Figure 6), predicted by the climate models.

i) The bushes and grassland habitats occurring at alpine and subalpine levels (Natura 2000 Code: $4070^{\circ}, 6150,6230^{\circ}$ ), were assessed as highly sensitive to temperature increase (Figure 5) and as medium sensitive to drought (Figure 6).

ii) The forest habitats (Natura 2000 Code: 9110, 91V0, 9410) were assessed as medium sensitive to increasing air temperature (Figure 5) and highly sensitive to moisture decrease (Figure 6).

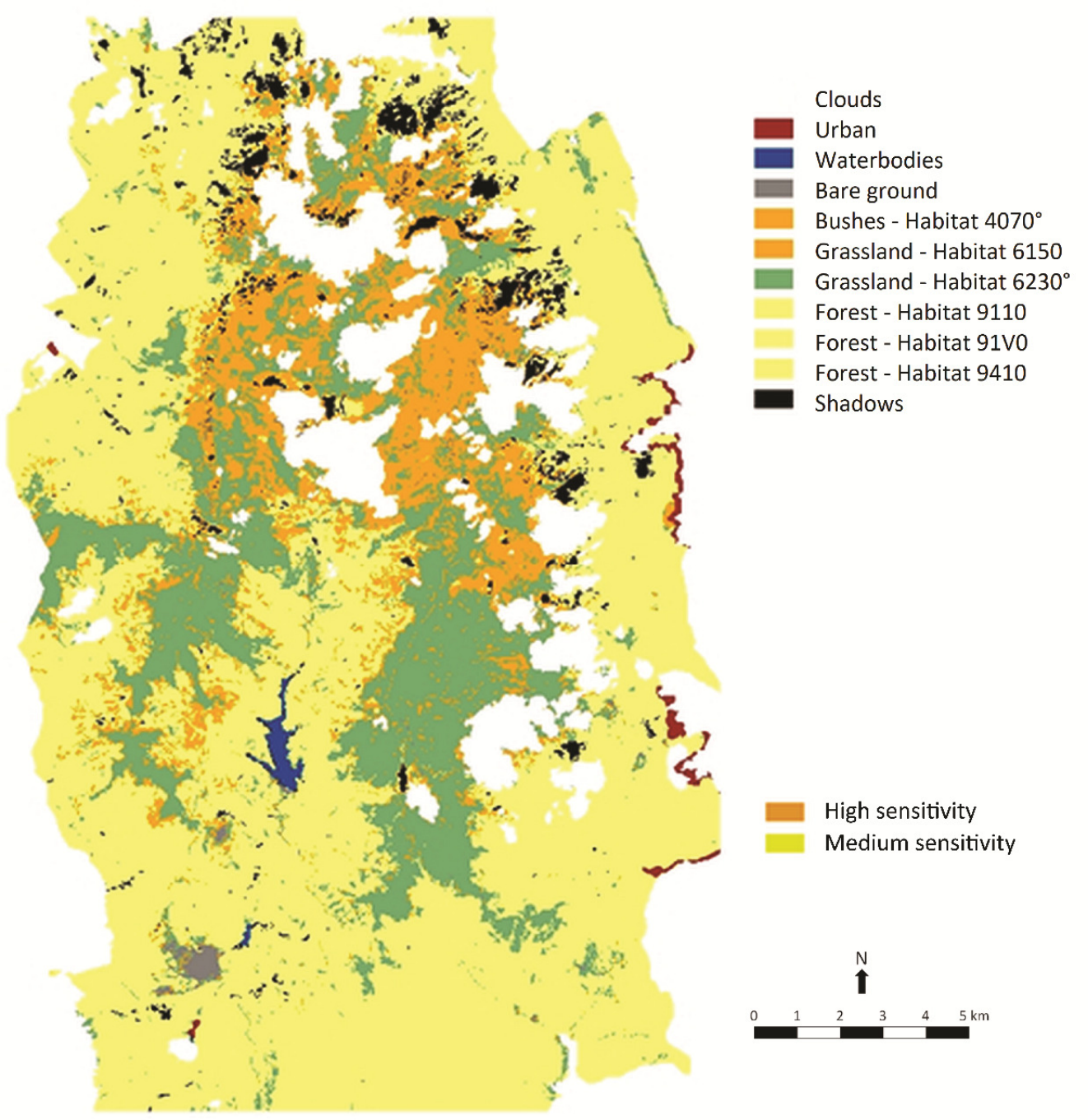

Figure 5. Bucegi Natural Park, Romania - Potential sensitivity of the selected Natura 2000 habitat types to temperature (source: adapted from 'current habitat types map', HABIT-CHANGE project, output 3.1.9.). This map contains more than 85000 polygons representing temperature sensitivity. Depending on the screen resolution or the print the image may appear spotted 


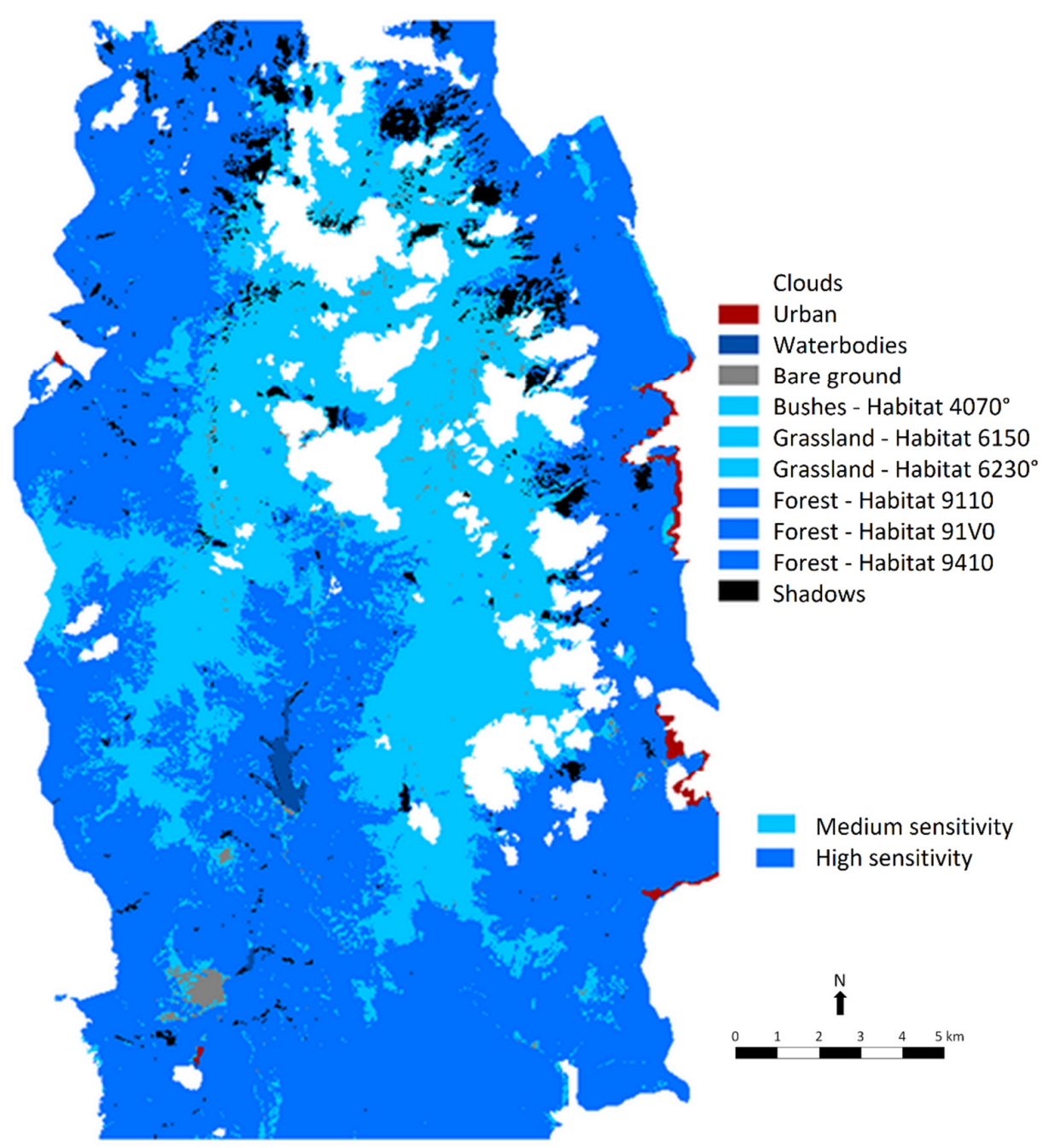

Figure 6. Bucegi Natural Park, Romania - Potential sensitivity of the selected Natura 2000 habitat types to moisture (source: adapted from 'current habitat types map', HABIT-CHANGE project, output 3.1.9.). This map contains more than 85000 polygons representing moisture sensitivity. Depending on the screen resolution or the print the image may appear spotted

For each of the considered habitat types a percentage assessment of the weight of ecological forms of the plants was made, using the plants' preferences for humidity and temperature (Table 3). The associated graphs emphasize the groups of ecological categories that express the taxa preferences for low temperatures (hekistothermophyte-psichrothermophye-microthermophyte) and high humidity values (mesophytemesohygrophyte-hygrophyte) respectively (Figures 7 and 8 ).

i) The plants from the alpine and subalpine levels (Natura 2000 Code: 4070* 6150, 6230) prefer low temperature (76-79\%), being evaluated as hekistothermophyte-psichrothermophytesmicrothermophytes. The proportion of eurithermophytes was between 13-23\% and the largest share was observed in the habitat type $4070^{*}$. In terms of humidity preferences, there are some variations, depending on the types of habitat, but most of the taxa $(65-75 \%)$ belong to the mesophyte-mesohygrophyte-hygrophyte categories. The euriphytes and xerophytes were not observed, but the xeromesophytes had been well represented (23-29\%) in the grassland habitats. 
More than half of the species (55-60\%) living in these habitats, prefer both low temperature and moisture (Table 3, Figures 7 and 8 ).

ii) Only $35-45 \%$ of the species inhabiting the forest habitats (Natura 2000 Code: 9110, 91V0, 9410) depend on low temperature (predominant microthermophytes and fewer hekistothermophytes and psychrothermophytes). The eurithermophytes have a share of $17-29 \%$ and were better represented in the habitat type 9410. In the forest habitat types, most of the plants (86-96\%) require sufficient humidity (mesophythes-mesohygrophytes-hygrophytes) and the majority are mesophytes and mesohygrophytes. The euriphytes $(0.84 \%)$ were observed only in the forest type 9410. Less than half (35-45\%) of the plants prefer cold and humid climatic conditions (Table 3, Figures 7 and 8 ).

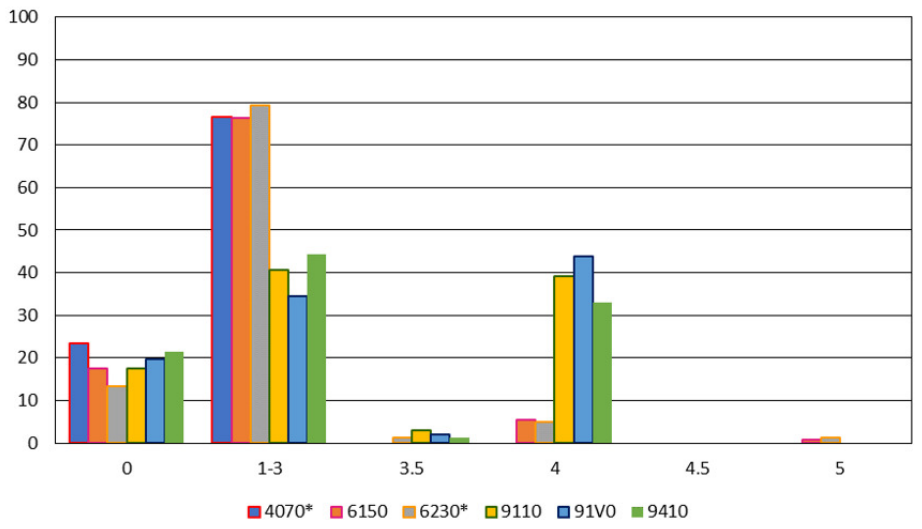

Figure 7. Spectrum indices of temperature features, for plant species representing the six Natura 2000 habitats of Bucegi Natural Park. Abscissa: numbers refer to the ecological categories (1-5) described in Table 3. Ordinate: percentage of species in each category

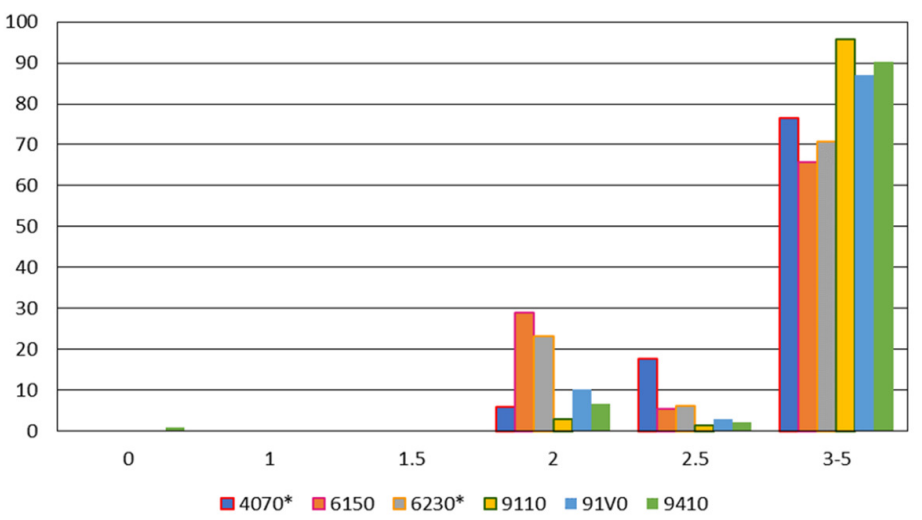

Figure 8. Spectrum indices of humidity features, for plant species representing the six Natura 2000 habitats of Bucegi Natural Park. Abscissa: numbers refer to the ecological categories (1-5) described in Table 3. Ordinate: percentage of species in each category

In the six selected habitats, 59 taxa of conservation value were identified, during the field survey. This represents $30 \%$ of the total plants with conservation value from Natura 2000 site Bucegi. Their preferences for moisture and temperature were expressed as percentage (Table 4, Figures 9 and 10).

In the habitat type 4070*, a single protected plant (Annex 1) was identified (Rhododendron myrtifolium Schott \& Kotschy - eurithermophyte and mesophyte). In grassland habitat type $6230^{*}$ and respectively 6150 
type, $66-85 \%$ of the plants with conservation value depend on low temperature (hekistothermophytepsichrothermophyte-microthermophyte), 60-70\% prefer moisture and 20-35\% are xeromesophytes. In forest habitats, $50-60 \%$ of plants with conservation value belong to microthermophyte category, $30-40 \%$ are mesothermophyte, and most of them (95-100\%) prefer conditions of sufficient humidity (mesophyte $\rightarrow$ hygrophyte).

Table 3. Selected Natura 2000 habitat types in the study area: species richness and ecological preferences for temperature and humidity, expressed as percentage (mean values/habitat type)

\begin{tabular}{|c|c|c|c|c|c|c|c|c|c|c|c|}
\hline \multirow{2}{*}{$\begin{array}{l}\text { Natura } \\
2000 \\
\text { habitat } \\
\text { code }\end{array}$} & \multirow{2}{*}{$\begin{array}{c}\text { Number } \\
\text { of } \\
\text { species }\end{array}$} & \multicolumn{10}{|c|}{ Temperature } \\
\hline & & 0 & 1 & 1.5 & 2 & 2.5 & 3 & 3.5 & 4 & 4.5 & \\
\hline $4070^{*}$ & 17 & 23.50 & 5.88 & 0 & 17.67 & 5.88 & 47.07 & 0 & 0 & 0 & \\
\hline 6150 & 131 & 17.55 & 24.42 & 6.87 & 9.16 & 4.58 & 31.30 & 0 & 5.36 & 0 & 0.76 \\
\hline $6230^{*}$ & 82 & 13.41 & 14.63 & 12.19 & 9.75 & 10.97 & 31.76 & 1.21 & 4.87 & 0 & 1.21 \\
\hline 9110 & 69 & 17.39 & 0 & 2.89 & 0 & 1.44 & 36.23 & 2.89 & 39.16 & 0 & 0 \\
\hline $91 \mathrm{V0}$ & 107 & 19.62 & 0 & 0 & 0 & 0 & 34.57 & 1.86 & 43.95 & 0 & 0 \\
\hline 9410 & 237 & 21.51 & 3.79 & 0.84 & 0.42 & 0 & 39.24 & 1.26 & 32.94 & 0 & 0 \\
\hline \multicolumn{12}{|c|}{ Humidity } \\
\hline & & 0 & 1 & 1.5 & 2 & 2.5 & 3 & 3.5 & 4 & 4.5 & 5 \\
\hline $4070^{*}$ & 17 & 0 & 0 & 0 & 5.88 & 17.65 & 35.30 & 29.41 & 5.88 & 5.88 & 0 \\
\hline 6150 & 131 & 0 & 0 & 0 & 29.00 & 5.34 & 48.09 & 6.10 & 9.95 & 0.76 & 0.76 \\
\hline $6230^{*}$ & 82 & 0 & 0 & 0 & 23.17 & 6.09 & 51.21 & 8.53 & 9.79 & 0 & 1.21 \\
\hline 9110 & 69 & 0 & 0 & 0 & 2.89 & 1.45 & 66.70 & 2.89 & 23.18 & 0 & 2.89 \\
\hline $91 \mathrm{~V} 0$ & 107 & 0 & 0 & 0 & 10.28 & 2.80 & 56.07 & 11.22 & 18.70 & 0.93 & 0 \\
\hline 9410 & 237 & 0.84 & 0 & 0 & 6.75 & 2.11 & 55.70 & 6.75 & 24.47 & 0.42 & 2.96 \\
\hline
\end{tabular}

Temperature (T): 0 = eurithermophyte, 1 = hekistothermophyte, 1.5 = hekistothermophyte-psichrothermophyte, 2 $=$ psichrothermophyte, $2.5=$ psichrothermophyte-microthermophyte, $3=$ microthermophyte, $3.5=$ microthermophyte-mesothermophyte, $4=$ mesothermophyte, $4.5=$ mesothermophyte-submesothermophyte, $5=$ subthermophyte. Humidity $(\mathrm{H}): 0=$ euriphyte, $1=$ xerophyte, $1.5=$ xerophyte-xeromesophyte, $2=$ xeromesophyte, 2.5 = xeromesophyte-mesophyte, 3 = mesophyte, 3.5 = mesophyte-mesohygrophyte, 4 = mesohygrophyte, $4.5=$ mesohygrophyte- hygrophyte, 5 = hygrophyte.

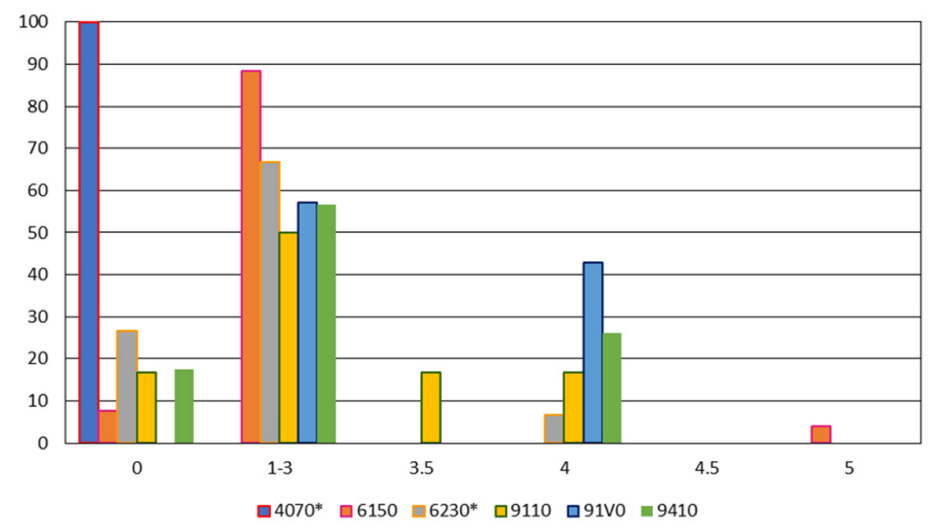

Figure 9. Spectrum indices of temperature features, for plant species with conservation value representing the six Natura 2000 habitats of Bucegi Natural Park. Abscissa: numbers refer to the ecological categories (1-5) described in Table 4. Ordinate: percentage of species in each category 
Table 4. Selected Natura 2000 habitat types in the study area: the richness of species of conservation value and their ecological preferences for temperature and humidity, expressed as percentage (mean values/habitat type)

\begin{tabular}{|c|c|c|c|c|c|c|c|c|c|c|c|}
\hline \multirow{2}{*}{$\begin{array}{c}\text { Natura } \\
2000 \\
\text { habitat } \\
\text { code }\end{array}$} & \multirow{2}{*}{$\begin{array}{c}\text { Number } \\
\text { of } \\
\text { species }\end{array}$} & \multicolumn{10}{|c|}{ Temperature } \\
\hline & & 0 & 1 & 1.5 & 2 & 2.5 & 3 & 3.5 & 4 & 4.5 & 5 \\
\hline $4070^{*}$ & 1 & 100 & 0 & 0 & 0 & 0 & 0 & 0 & 0 & 0 & 0 \\
\hline 6150 & 26 & 7.69 & 30.77 & 3.84 & 19.23 & 3.85 & 30.77 & 0 & 0 & 0 & 3.85 \\
\hline $6230^{*}$ & 15 & 26.67 & 26.67 & 6.67 & 13.32 & 0 & 20.00 & 0 & 6.67 & 0 & 0 \\
\hline 9110 & 6 & 16.67 & 0 & 0 & 0 & 0 & 50.00 & 16.66 & 16.67 & 0 & 0 \\
\hline $91 \mathrm{V0}$ & 7 & 0 & 0 & 0 & 0 & 0 & 57.15 & 0 & 42.85 & 0 & 0 \\
\hline 9410 & 23 & 17.39 & 0 & 4.35 & 0 & 0 & 52.18 & 0 & 26.08 & 0 & 0 \\
\hline \multicolumn{12}{|c|}{ Humidity } \\
\hline & & 0 & 1 & 1.5 & 2 & 2.5 & 3 & 3.5 & 4 & 4.5 & 5 \\
\hline $4070^{*}$ & 1 & 0 & 0 & 0 & 0 & 100 & 0 & 0 & 0 & 0 & 0 \\
\hline 6150 & 26 & 0 & 0 & 0 & 34.62 & 3.85 & 42.30 & 11.53 & 3.85 & 3.85 & 0 \\
\hline $6230^{*}$ & 15 & 0 & 0 & 0 & 20.00 & 6.67 & 46.67 & 13.33 & 13.33 & 0 & 0 \\
\hline 9110 & 6 & 0 & 0 & 0 & 0 & 0 & 66.67 & 0 & 33.33 & 0 & 0 \\
\hline $91 \mathrm{~V} 0$ & 7 & 0 & 0 & 0 & 0 & 0 & 42.86 & 28.57 & 28.57 & 0 & 0 \\
\hline 9410 & 23 & 0 & 0 & 0 & 4.35 & 0 & 43.48 & 17.39 & 26.08 & 8.70 & 0 \\
\hline
\end{tabular}

Temperature (T): 0 = eurithermophyte, 1 = hekistothermophyte, 1.5 = hekistothermophyte-psichrothermophyte, 2 $=$ psichrothermophyte, $2.5=$ psichrothermophyte-microthermophyte, $3=$ microthermophyte, $3.5=$ microthermophyte-mesothermophyte, $4=$ mesothermophyte, $4.5=$ mesothermophyte-submesothermophyte, $5=$ subthermophyte. Humidity $(\mathrm{H}): 0=$ euriphyte, $1=$ xerophyte, $1.5=$ xerophyte-xeromesophyte, $2=$ xeromesophyte, 2.5 = xeromesophyte-mesophyte, $3=$ mesophyte, $3.5=$ mesophyte-mesohygrophyte, $4=$ mesohygrophyte, $4.5=$ mesohygrophyte- hygrophyte, 5 = hygrophyte.

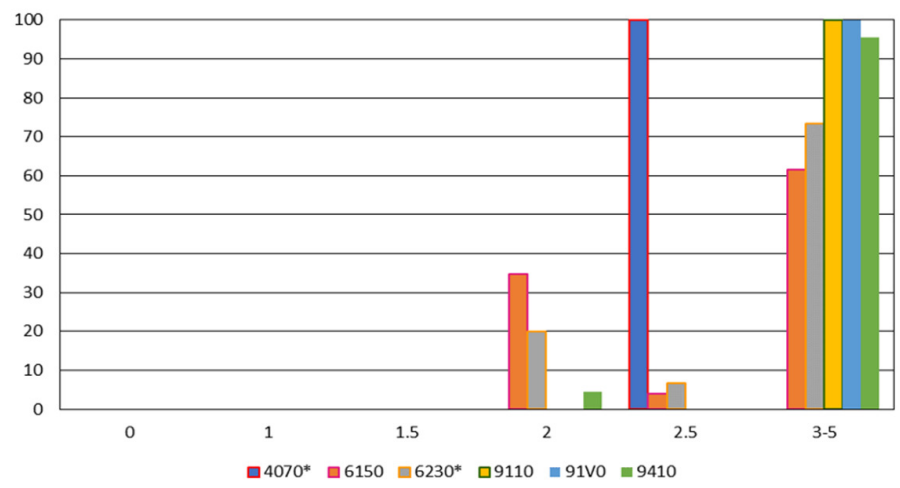

Figure 10. Spectrum indices of humidity features, for plants species with conservation value representing the six Natura 2000 habitats of Bucegi Natural Park. Abscissa: numbers refer to the ecological categories (1-5) described in Table 4. Ordinate: percentage of species in each category

\section{Sensitivity of plants with conservation value from the whole Bucegi Natura 2000 site perimeter}

In this study 200 plant species, subspecies and varieties with conservation value were evaluated regarding their sensitivity to climate changes. Their categories of 'threatened' and their endemic status accords to several legislative documents and bibliographic resources (Table 5, Annex 1).

Regarding species which are included in different categories of the IUCN Red List (Annex 1), 38 are potentially sensitive to humidity decrease (most orchids, 27 taxa), and 14 taxa are potentially sensitive to temperature increase. 12 taxa are potentially sensitive to both factors: Campanula patula subsp. abietina, 
Dactylorhiza cordigera, D. maculata, D. sambucina, Eriophorum scheuchzeri, Gentiana lutea, Gymnadenia conopsea, G. nigra, Ligularia sibirica, Pseudorchis albida, Tozzia carpathica, Traunsteinera globosa.

Table 5. The numerical situation of plants with conservation value in the various legislative documents and bibliographic resources

\begin{tabular}{|l|c|}
\hline \multicolumn{1}{|c|}{ Legislative documents / bibliographic resources } & Number of taxa \\
\hline Red List of vascular plants in Romania (Oltean et al. 1994), declared as 'Rare' and 'Vulnerable' & 173 \\
\hline IUCN Red List, as 'Data Deficient', 'Least Concern' or 'Near Threatened' (Bilz et al. 2011) & 44 \\
\hline Habitat Directive Annexes II, IV, V & 9 \\
\hline CITES Appendix II & 32 \\
\hline $\begin{array}{l}\text { Sârbu et al. 2013, endemic to the Carpathian Mountains (Poa molineri subsp. glacialis, endemic to } \\
\text { the Bucegi Mountains) and Carpathian Balkan area }\end{array}$ & 57 \\
\hline
\end{tabular}

Table 6. Analysis of ecological indices for moisture $(\mathrm{H})$ and temperature $(\mathrm{T})$ for 200 plant species of conservation value from Natura 2000 site Bucegi

\begin{tabular}{|l|l|l|l|l|l|l|l|l|l|l|}
\hline & $\mathbf{0}$ & $\mathbf{1}$ & $\mathbf{1 . 5}$ & $\mathbf{2}$ & $\mathbf{2 . 5}$ & $\mathbf{3}$ & $\mathbf{3 . 5}$ & $\mathbf{4}$ & $\mathbf{4 . 5}$ & $\mathbf{5}$ \\
\hline $\mathbf{H}$ & 1 & 0 & 3 & 33 & 22 & 74 & 23 & 31 & 7 & 6 \\
\hline $\mathbf{T}$ & 20 & 20 & 7 & 40 & 3 & 50 & 22 & 32 & 2 & 4 \\
\hline
\end{tabular}

Shaded cells: Carpathian endemics. Humidity $(\mathrm{H}): 0$ = euriphyte, 1 = xerophyte, 1.5 = xerophyte-xeromesophyte, 2 = xeromesophyte, $2.5=$ xeromesophyte-mesophyte, $3=$ mesophyte, $3.5=$ mesophyte-mesohygrophyte, $4=$ mesohygrophyte, $4.5=$ mesohygrophyte- hygrophyte, $5=$ hygrophyte. Temperature $(\mathbf{T}): 0=$ eurithermophyte, $1=$ hekistothermophyte, $1.5=$ hekistothermophyte-psichrothermophyte, $2=$ psichrothermophyte, $2.5=$ psichrothermophyte-microthermophyte, 3 = microthermophyte, 3.5 = microthermophyte-mesothermophyte, $4=$ mesothermophyte, $4.5=$ mesothermophyte-submesothermophyte, 5 = subthermophyte.

For the species nominated in the Annexes of the Habitat Directive, ecological preferences with respect to temperature and humidity are as follows:

i) Annexes II and IV: Campanula serrata (mesophyte, microthermophyte-mesothermophyte), Draba dorneri (xeromesophyte, psychrothermophyte), Iris aphylla (xeromesophyte, eurithermophyte), Ligularia sibirica (mesohygrophyte-hygrophyte, microthermophyte), Tozzia carpathica (mesohygrophyte, microthermophyte),

ii) Annex V: Arnica montana (mesophyte, microthermophyte-mesothermophyte), Galanthus nivalis (mesophyte, mesothermophyte), Gentiana lutea (mesophyte, microthermophyte), Lycopodium alpinum (mesophyte, psychrothermophyte). Only four taxa are potentially sensitive to both factors: Gentiana lutea, Ligularia sibirica, Lycopodium alpinum, Tozzia carpathica.

Among the plants included in CITES Appendix II, 28 taxa are sensitive to moisture decrease, 7 to temperature increase and 6 to both parameters: Dactylorbiza sambucina, D. cordigera, D. maculata, Gymnadenia conopsea, G. nigra and Pseudorchis albida.

The analysis of the endemic taxa in the Carpathian Mountains underline their specific preferences to temperature and humidity:

- In relation to soil moisture: 2 xerophyte-xeromesophytes (Hesperis moniliformis, Saxifraga mutata subsp. demissa), 23 xeromesophytes, 5 xeromesophyte-mesophytes, 15 mesophytes, 5 mesophytemesohygrophytes (Achillea oxyloba subsp. schurii, Cardaminopsis neglecta, Dianthus glacialis subsp. gelidus, Plantago atrata subsp. carpatica, Veronica baumgartenii), 7 mesohygrophytes (Aconitum vulparia subsp. lasianthum, Cardamine glanduligera, Heracleum palmatum, Hesperis nivea, $H$. oblongifolia, Ranunculus carpaticus, Symphytum cordatum).

- In relation to air temperature: one eurithermophyte (Draba aizoides subsp. zmudae), 6 hekistothermophytes (Astragalus australis subsp. bucsescii, Dianthus glacialis subsp. gelidus, Erigeron 
nanus, Festuca bucegiensis, Hesperis oblongifolia, Thesium kernerianum), 16 psychrothermophytes, 14 microthermophytes, 10 microthermophyte-mesothermophytes, 8 mesothermophytes, one mesothermophyte-submesothermophytes and one subthermophyte.

- Species endemic to the Carpathian Mountains that could be affected both by rising temperatures and the decrease in rainfall are: Achillea oxyloba subsp. schurii, Anemone transsilvanica, Astragalus australis subsp. bucsescii, Cardaminopsis neglecta, Cerastium transsilvanicum, Dianthus glacialis subsp. gelidus, Erigeron nanus, Festuca carpathica, Heracleum carpaticum, Hesperis nivea, H. oblongifolia, Phyteuma vagneri, Plantago atrata subsp. carpatica, Ranunculus carpaticus, Scabiosa lucida subsp. barbata, Scorzoneroides pseudotaraxaci, Symphytum cordatum, Veronica baumgartenii.

The analysis of ecological indices for humidity and temperature (Popescu and Sanda, 1998, Ciocârlan, 2009), addressed to all the 200 plants of the Bucegi Mountains considered in this study, underlines that more than half range among the group of hekistothermophyte-microthermophyte (120 taxa/60\%), and more than half are classified as mesophytes-hygrophytes (141 taxa/70.5\%; Table 6 and Figures 11 and 12). Sensitive to both parameters (temperature increase and decrease of rainfall) are 88 protected taxa (44\%) (Figure 12).

All the taxa nominated in IUCN Red List taxa recorded in this study are potentially sensitive to drought $(85 \%)$ or warming $(32 \%)$ to a different extent, and $27 \%$ are sensitive to both factors. Except Campanula patula subsp. abietina, all of them are rare species in Romania, according to Oltean et al. (1994).

In the case of plants listed in the Habitat Directive and CITES annexes, the aspects are more heterogeneous. According to these two documents most of the species included in the category 'sensitive to drought', and one third of those included in the category 'sensitive to warming', can be considered as potentially sensitive to the predicted changes of temperature and moisture regime. More than two thirds of the Carpathian endemic species considered in this study are sensitive to warming, about $46 \%$ are sensitive to moisture decrease, and $32 \%$ are potentially sensitive to both factors.

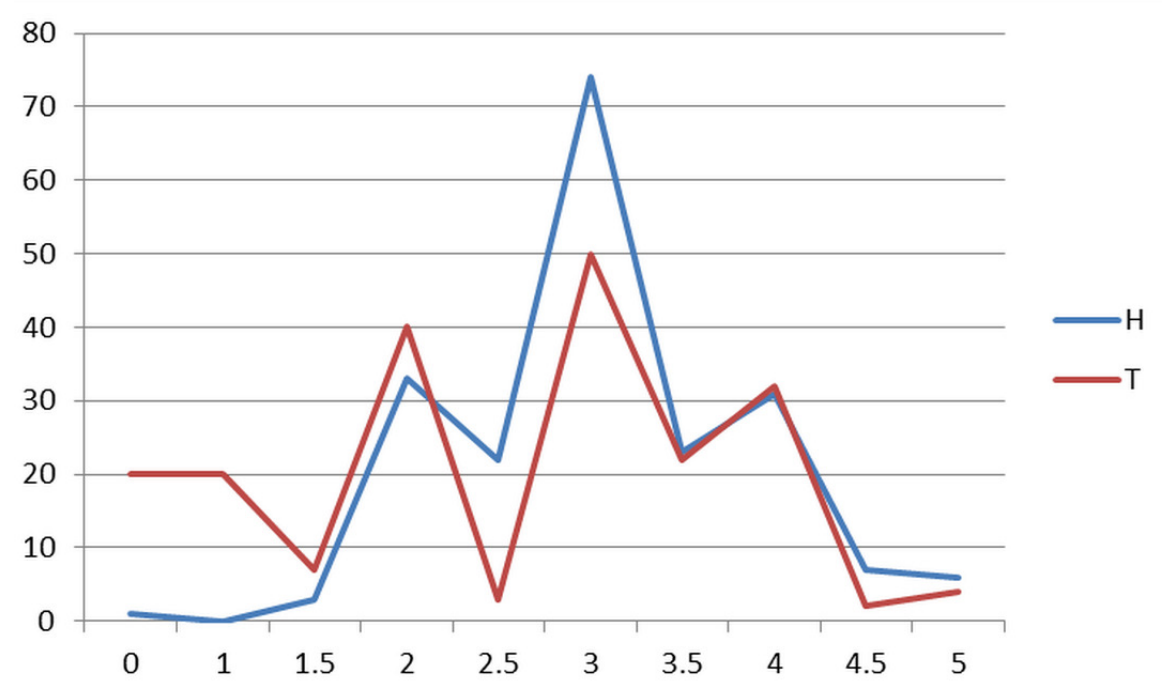

Figure 11. Spectrum indices for humidity $(\mathrm{H})$ and temperature $(\mathrm{T})$ features for plant species with conservation value of Natura 2000 site Bucegi (Annex 1). Abscissa: numbers refer to the ecological categories $(1-5)$ described in Table 3 . Ordinate: number of species in each category 


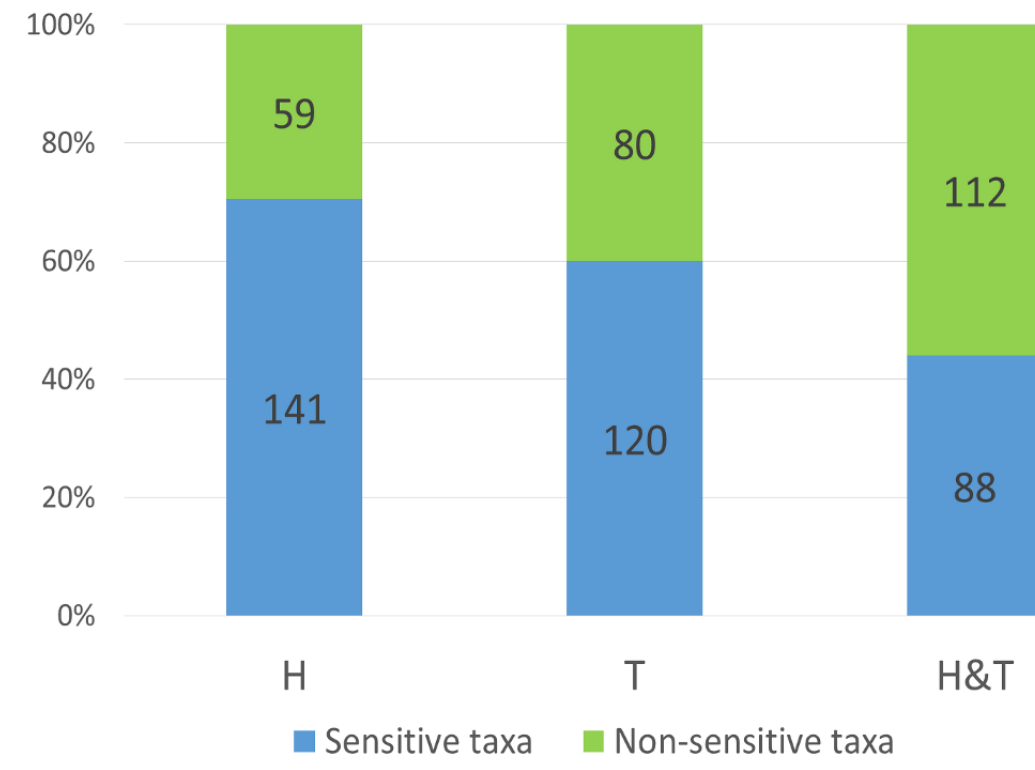

Figure 12. Share of species of conservation value of Natura 2000 site Bucegi (Annex 1) potentially sensitive to moisture ( $\mathrm{H}$ - humidity) decrease, to air temperature ( $\mathrm{T}$ - temperature) increase, and to both parameters $(\mathrm{H} \& \mathrm{~T})$

\section{Discussion}

The habitats of the Bucegi Natural Park may be exposed to a progressive increase in the mean annual air temperature, to longer drought periods in spring and summer, and to a decrease in snow pack thickness and duration, towards the end of this century (Figure 4). Climate projections for other high mountain areas in Europe, such as the Alps, show also a trend of warming and a possible increase of temperature between $+1{ }^{\circ} \mathrm{C}$ and $+2{ }^{\circ} \mathrm{C}$, until 2100 (Förster $e t$ al., 2014).

The assessment of the potential sensitivity of the six Natura 2000 habitat types, considered in this study (code: $4070^{*}, 6150,6230^{*}, 9110,91 \mathrm{~V} 0,9410$ ), suggests that they may be sensitive to a different extent to the predicted temperature and humidity changes. They have a different floristic composition, developed by plants with different requirements to temperature and moisture, adapted to live in specific environmental conditions, which allow them to survive, to grow and spread.

$>4070^{*}$ Bushes with Pinus mugo and Rhododendron myrtifolium, is a typical habitat for the subalpine level of Bucegi Mountain (1400-2000 m altitude). It requires low temperatures $\left(+2.2--0.2{ }^{\circ} \mathrm{C}\right)$, sufficient humidity (1250-1425 mm/year) and snow (Mountford et al., 2008). This habitat shelters only a few plant species and is dominated (90\%) by Pinus mugo Turra, a protected plant in Romania. It grows in a compact way, covering most of the habitat. The dominant species Pinus mugo (psichrothermophyte) (Popescu and Sanda, 1998) and $70 \%$ of the other species of phytocoenosis are depending on low temperature (hekistothermophytes, psichrothermophytes and microthermophytes). $36 \%$ of the plants are mesophytes and prefer a moderately humid substrat, but $40 \%$, including the dominant specie Pinus mugo are mesophyte-mesohygrophyte and prefer a higher humidity. Approximately $66 \%$ of the species of this habitat type, develope under conditions of low temperature and humidity (Table 3) (e.g. Calamagrostis villosa (Chaix) J.F. Gmel., Caltha palustris L., Festuca airoides Lam., Homogyne alpina (L.) Cass., Pinus mugo, Soldanella hungarica Simonk., Vaccinium myrtillus L.). 
> 6150 Siliceous alpine and boreal grasslands, are considered a glacial relict (Doniță et al. 2005), including plant communities growing on the high crests of the mountains at alpine level (1550-2500 m altitude), preferring low temperature (annual average: $+3--2.5{ }^{\circ} \mathrm{C}$ ) and humidity $(1100-1450 \mathrm{~mm} /$ year) (Mountford et al., 2008). These short grasslands are dominated by species like Agrostis rupestris All. (hekistothermophyte and mesophyte), Festuca airoides Lam. (syn. Festuca supina Schur) (psychrothermophyte and mesophyte) and Potentilla aurea L. subsp. chrysocraspeda (Lehm.) Nyman (psychrothermophyte, mesophyte). About $75 \%$ of the plants require low temperatures (hekistothermophyte and psichrothermophyte, microthermophyte), 65\% prefer a humid substrate (mesophyte, mesohygrophyte and hydrophyte) and more than half (55\%) need both kind of conditions for their development: low temperatures and edaphic humidity. Of the 26 taxa with conservation value observed in this type of habitat, $75 \%$ are predominantly hekistothermophyte and psichrothermophyte and $54 \%$ are predominantly mesophytes (Table 3). The endemic plant Dianthus glacialis Haenke subsp. gelidus (Schott, Nyman \& Kotschy) Tutin, the rare plants Androsace chamaejasme Wulfen, Erigeron uniflorus L., Kobresia myosuroides (Vill.) Fiori, Loiseleuria procumbens (L.) Loisel., Gymnadenia nigra (L.) Rchb.f. (syn. Nigritella nigra) are only few of the species highly dependent on low temperature (hekistothermophytes, psichrothermophytes).

$>6230$ Species-rich Nardus grasslands on siliceous substrates in mountain areas (and submountain areas in Continental Europe), comprise the most wide-spread grassland type (35-40\%), within the pasture area (800-2070 m altitude) of the Bucegi Mountains (Doniță et al., 2005). Dominant species are Nardus stricta L. (80-90\%) and Festuca airoides (mesophyte and psichrothermophyte). Nardus stricta is a xeromesophilicmesohygrophilic and eurithermophilic plant (Popescu and Sanda, 1998), which can cope, for a short period of time, with variation in temperature (annual average: $+6--1.5^{\circ} \mathrm{C}$ ) and humidity $(800-1400$ $\mathrm{mm} /$ year) (Mountford et al., 2008), but it is sensitive to prolonged drought or long-term high air temperature (Puşcaru et al., 1956). A ratio of $80 \%$ of all species comprised within this vegetation type requires low temperature (hekistothermophyte, psichrothermophyte and microthermophyte) and $70 \%$ need moist conditions (mesophytes, mesophyte-mesohygrophyte) (Table 3). More than half of the species (58\%) need low temperature and sufficient humidity for their development. The value of this habitat, which is a priority for conservation, is provided by the presence of up to 15 protected plants: rare [Androsace chamaejasme, Dactylorhiza viridis (L.) R.M.Bateman, Pridgeon \& M.W.Chase, Erigeron uniflorus, Gentiana acaulis L., Gymnadenia nigra, Oxytropis halleri Koch, Veronica alpina L.], endemic (Dianthus glacialis subsps. gelidus), and globally protected [Arnica montana L., Campanula patula L. subsp. abietina (Griseb. \& Schenk) Simonk., Gymnadenia conopsea (L.) R.Br. subsp. conopsea, Pseudorchis albida (L.) Á. Löve \& D. Löve]. All these taxa depend on low temperature (hekistothermophytes, psychrothermophytes, microthermophytes) and snow, and prefer a humid soil (mesophytes, mesohygrophytes).

$>9110$ Luzulo-Fagetum beech forests, include acidophilic beech forests, beech and fir forests, or beech, fir and spruce forests growing at 600 to $1350 \mathrm{~m}$ altitude. They require precipitation of $700-1300 \mathrm{~mm} /$ year and average annual temperatures of +3 to $+8{ }^{\circ} \mathrm{C}$ (Mountford et al., 2008). The edificatory tree species are Fagus sylvatica L., Abies alba Mill. (mesophyte-mesohygrophyte and mesothermophyte) and Picea abies (L.) H. Karst., (mesophyte-hygrophyte and microthermophyte). The characteristic herbaceous taxa are Festuca drymeja Mert. \& W.D.J. Koch, Symphytum cordatum Waldst. \& Kit ex Willd. (mesohygrophyte, microthermophyte), Hieracium transsilvanicum Heuff. (mesophyte, eurithermophyte) and Luzula luzuloides (Lam.) Dandy \& Wilmott (mesophyte, microthermophyte). About $95 \%$ of the forest plants are strongly dependent on edaphic humidity (mesophyte-hygrophyte) and about 40\% prefer low air temperatures (hekistothermophyte, psichrothermophyte amd microthermophyte) (Table 3). Less than half of the species (38\%) need both low temperatures and enough humidity during the vegetation period. 
This type of habitat shelves a few protected plants with quite different demands on humidity and temperature, as for example: endemic as Anemone transsilvanica (Fuss) Heuff. (mesophyte, mesothermophyte), Ranunculus carpaticus Herbich (mesohygrophyte, microthermophyte) and rare as Dactylorhiza fuchsii (Druce) Soó (mesophyte, eurithermophyte), Dactylorhiza maculata (L.) Soó (mesohygrophyte, microthermophyte), Doronicum carpaticum (Griseb. \& Schenk) Nyman (mesohygrophyte, psichrotermophyte), Neotia nidus-avis (L.) Rich. (mesophyte, mesothermophyte).

> 91V0 Dacian beech forests (Symphyto-Fagion), is a common forest type throughout the Carpathian ridge from 500 to $1450 \mathrm{~m}$ altitude and requires average annual temperature of $+3-+8^{\circ} \mathrm{C}$ and rainfall of 750 $1200 \mathrm{~mm} /$ year (Mountford et al., 2008). The habitat is characterised by beech, spruce and fir forests, dominated by Fagus sylvatica (mesophyte-mesohygrophyte and mesothermophyte). The characteristics herbaceous plants are mesophyte-mesohygrophyte and microthermophyte taxa like Pulmonaria rubra Schott, Leucanthemum rotundifolium DC. or Symphytum cordatum. Over $85 \%$ of the species recorded, have medium to high water requirements (mesophyte-hygrophyte), and $35 \%$ prefer cold air temperature (Table 3). One third of the species (31\%) need both low temperature and sufficient moisture. The seven identified taxa with conservation value belong to mesophyte and mesohygrophyte categories. Five are microthermophytes (Gymnadenia conopsea subsp. conopsea, Larix decidua Mill. var. carpatica Domin, Leucanthemum rotundifolium, Pulmonaria rubra, Ranunculus carpaticus) and two are mesothermophytes (Corallorbiza trifida Châtel. and Neottia vidus-avis).

$>9410$ Acidophilous Picea forests at the montane to alpine levels (Vaccinio-Piceetea), define a group of Picea forests wide-spread in the Romanian Carpathians, between 1000-1850 m altitude. They require average annual temperatures of $+1.5-+5^{\circ} \mathrm{C}$ and precipitation between $900-1400 \mathrm{~mm} /$ year (Mountford $e t$ al., 2008). The dominant tree is Picea abies (L.) H. Karst. (mesophyte-hygrophyte and microthermophyte). Characteristic vascular plants like Lycopodium selago L., L. annotinum L., Oxalis acetosella L. and Sorbus aucuparia L. are mesohygrophyte and microthermophyte-mesothermophyte taxa. Luzula sylvatica (Huds.) Gaudin, Soldanella hungarica Simonk. and Vaccinium vitis-idaea L. are dominant vascular plants, depending more on edaphic humidity (mesohygrophytes and microthermophytes). The majority (90\%) of the species (mesophyte $\rightarrow$ hygrophyte) of this forest type prefer humid soil (Table 3). Only $45 \%$ are dependent on low temperatures (many microthermophyte), and more than one third (42\%) need both low temperatures and moisture. Of the 23 taxa with conservation value, identified in this type of habitat, $96 \%$ belong to mesophyte and mesohygrophyte categories and only $50 \%$ are microthermophytes. Some rare orchids such as Dactylorbiza maculata and Gymnadenia conopsea subsp. conopsea and the endemic Ranunculus carpaticus belong to this category.

The results of this study indicate that bushes $\left(4070^{*}\right)$ and grassland habitat $\left(6150\right.$ and $\left.6230^{*}\right)$ can be considered as highly sensitive to warming but also as medium sensitive to drought. Their plants prefer low temperature and snow to a high proportion (70-80\%) and many of the dominant taxa can be considered warm sensitive (hekistothermophyte and psichrothermophyte). Similar information was provided by Erschbamer $e t$ al. (2009) studies, referring to alpine grasslands from the Southerm Alps. Alpine ecosystems dependent on low temperatures, snow and rainfall, generally create optimal conditions for highly specialized mountain species (Burrows, 1990; Körner, 1999). According to Ozenda and Borel (1991) plants from high altitude, which strongly depend on vernalisation and snow, will be the most vulnerable to warming and the alpine habitats can be considered among the most affected by climate change (Inouye, 2019). To a certain extent, the ecological preferences of plants well adapted to the existing climate conditions, may be also useful in predicting this trend. Studies on montain areas in Europe (Alps, Balkans, Carpathian s.o.) show that reduced species tolerance to changes, promoted a higher rate of loss of species (Thuiller $e$ t al., 2005). These also claim that the risk of extinction of alpine plants in Europe will be higher even in moderate scenarious that use only two climatic variables (temperature and humidity) (Thuiller et al., 2005). Gottfried et al. (1999) predicts loss of areas 


\section{4}

suitable for some nival species, if temperature will increase by 1 to $2 \mathrm{~K}$ and Barros et al. (2018) point out that prolonged drought can also lead to the loss of characteristic alpine species. But Theurillat et al. (1998) and Theurillat and Guisan (2001) underline that other high mountain ranges like the Alps appear to have a natural inertia and that alpine and nival species will be affected only when temperature will increase more than 3 to $4 \mathrm{~K}$. According to Matteodo et al. (2016) an increase in temperature by $4{ }^{\circ} \mathrm{C}$, in the period 2071-2100, will reduce the snow volume by $50 \%$ and the alpine and subalpine grasslands of the Alps will undergo important changes.

Rapid climate change in wet and cold high mountain areas like Bucegi Mountain are open upward migration routes. The progressive reduction of cold mountain habitats will enhance the decline of species better adapted to low temperature, while those adapted to warmer conditions will extend their area (Pauli et al., 1996). This process was reported by Gottfried et al. (2012), calling it 'thermophilization'. The expansion of thermophilic vascular taxa, and the moderate decline in regional endemic flora, was also reported by Stanisci $e t$ al. (2016) for the Apennines, as a response to warming. However, data from the High Alps (Pauli et al., 2007), referring to the period 1994-2004, indicate an ongoing decline of the cold-adapted species and an expansion of plants from lower elevations. The nival Saxifraga oppositifolia L. from the first category and the alpine Viola alpina Jacq. from the second category, are also present in the flora of Bucegi Mountains. The migration of species from lower altitude has already been reported not only in the Alps (Pauli et al., 2003), but also in the Rocky Mountains (2450-3050 m altitude), from Glaciar National Park, Montana, USA (Lesica and McCune, 2004). The upward migration of some thermophilic plants as Cardamine pratensis L., Deschampsia caespitosa (L.) P. Beauv., Gnaphalium sylvaticum L. was also observed in our study in the case of Natura 2000 habitat type 6150.

Forest habitat types are particularly sensitive to the expected climatic changes (Lindner et al., 2010), especially to drought (Gilliam, 2016). In the Bucegi Mountains the evaluated forest plant communities' habitats: 9110,91V0, 9410, and especially the trees, depend on high humidity (85-96\%) and the extensive drought may have directly damaging effects on tree species. One of the most vulnerable forest types can be considered the acidophilous Picea forests (Natura 2000 code: 9410), with a species composition, dominated by mesophilic, up to hygrophilic plants, respectively.

According to Frischbier et al. (2014), the typical species composition of Picea forests, if influenced by moderately warming conditions, may be significantly threatened by climate-induced spreading of beech (Fagus sylvatica), a mesothermophilic plant, until the middle of this century. Since climate models predict a significant increase in water deficit after 2050, tree species depending on water supply may be affected, including Fagus sylvatica. From this time on beech forests like "Luzulo-Fagetum beech forests" and "Dacian beech forests (Symphyto-Fagion)" will be subject to stronger climate change impact.

Hekistothermophytes, psychrothermophytes, mesohygrophytes and hygrophytes, as well as the microthermophytes and mesophytes, may be potentially affected by the predicted changes in climate in different ways (Sârbu et al., 2013; Sârbu et al., 2014). These ecological categories include most plants from high mountains of Europe and other geographic regions. Literature already provides information about the unfavourable effects of climate change on several protected alpine plants. Some of them are present in the flora of Bucegi Mountain, like Pinguicula vulgaris (Lesica and McCune, 2004), Saxifraga oppositifolia (Pauli et al., 1996), and Veronica alpina (Schöb et al., 2008).

Under the changing climatic conditions expected for this century, plants can have some options (Theurillat and Guisan, 2001; Corlett and Westcatt, 2013): persisting in the modified climates by adaptation, migrating to more suitable climate areas or going extinct. This was also specified in the EEA Report - Climate change, impacts and vulnerability in Europe (EEA, 2012), where adaptation, migration and colonisation of new habitats, but also extinction, as a result of loss of suitable climatic conditions for species in protected areas, are considered as significant response mechanisms to climate change pressures. In this respect, it is possible that 
some of the endemic species of the Bucegi Mountains, which belong to xerophytes-xeromesophytes (Hesperis moniliformis, Saxifraga mutata L. subsp. demissa (Schott \& Kotschy) D.A. Webb) or to mesothermophytes categories [Athamanta turbith (L.) Brot. subsp. hungarica (Borbás) Tutin, Centaurea pinnatifida Schur, Crocus banaticus J. Gay, Dianthus carthusianorum L. subsp. tenuifolius (Schur) Hegi, Erysimum witmannii Zaw. subsp. transsilvanicum P.W. Ball, Koeleria macrantha (Ledeb.) Schult. subsp. transsilvanica (Schur) A. Nyár., Silene nutans L. subsp. dubia (Herbich) Zapal.] may cope with warm and drier conditions in the future, to survive and to spread.

Other studied species requiring low temperature and moisture may accomplish an upward migration yet endangering the existence of the cryophilic plants (Pauli et al., 2003). A migration process towards higher altitudes was reported by Erschbamer et al. (2009) for the Southern Alps, concerning Androsace obtusifolia All., Erigeron uniflorus and Oxyria digyna (L.) Hill. These species, also present in the flora of the Bucegi Mountains, are rare hekistothermophytes and mesophytes plants. Other hekistothermophytes, endemic to the Carpathians and with a capacity of migrating upward are: Astragalus australis (L.) Lam. var. bucsescii (Jav.) Gusul., Erigeron nanus Nutt., Festuca bucegiensis Markgr - Dann., Hesperis oblongifolia Schur, Thesium kernerianum Simonk. The question remains, if these endemic plants will be able to move fast enough to disperse naturally beyond the limits of their existing habitats, to keep up with climate change pressures.

The third option is extinction, which could strike the taxa heavily dependent on low temperatures, humidity and snow. Their persistence will be endangered as many of them are unable to move rapidly enough or because nival zones will be completely lost (Grabher et al., 1994). This category includes protected plants at high altitude in the Bucegi Mountains, which are highly sensitive to warming, e.g. Dianthus glacialis subsp. gelidus, and Hesperis moniliformis.

According to Engler et al. (2011), the impact of climate change on the flora of the European mountains will be different, according to the level of increased warming accompanied by decreased precipitation. In this respect, the sensitivity of plants of the Carpathians to climate change was considered to be medium, when compared with the situation in other mountain ranges of Europe (e.g. Spanish Pyrenees, Austrian Alps) (Engler et al., 2011). But, with respect to protected plants growing at high altitude in the Carpathians in restrictive ecological life conditions, we suggest that a possible high sensitivity to temperature and humidity may be taken into consideration, especially in the case of the predicted combination of less precipitation and warming.

\section{Conclusions}

This research represents an attempt to provide a first forecast on very possible changes in vegetation, in the Bucegi territorial mountain unit, in condition of the changes in temperature and humidity, predicted for this century. The following aspects support the uniqueness of the results: i) the forecast on vegetation development is based on the climate scenarious, ii) all the plants with conservation value (200 taxa) from the Bucegi Natural Park were considered, iii) a whole mountain area is being described by Sat - image interpretation with GIS.The trends of the temperature and humidity regime in Bucegi Natural Park, in this century, consist in a clear and progressive rise and in serious changes of the water regime. As a scenario of long-term change, the microthermophilic and the hydrophilic plants of the Bucegi Mountains can be considered as potentially sensitive to predicted warming and drought. About $80 \%$ of the plants with conservation value evaluated in this study are included in these categories. The sensitivity can be theoretically higher for taxa that combine the two requests: more than half of the plants in alpine and subalpine habitats, more than a third of the plants in forest habitats and almost half of the plants with conservation value in the Natura 2000 site Bucegi. All six habitat types considered in this study were assessed as potentially sensitive to temperature and humidity changes, predicted for this century. Alpine and subalpine habitats may be considered more dependent on low 
476

temperature, which is associated with the presence of snow, and forest habitats may be considered potentially more sensitive to drought.

\section{Acknowledgements}

The presented activities and results were developed in the framework of the HABIT-CHANGE project: Adaptive management of climate induced changes of habitats diversity in protected areas, implemented through the CENTRAL EUROPE Programme and co-financed by the ERDF. Iris Wagner-Lücker is thanked for her work on graphs.

\section{Conflict of Interests}

The authors declare that there are no conflicts of interest related to this article.

\section{References}

Aklemade R, Bakkenes M, Eickhout B (2011). Towards a general relationship between climate change and biodiversity: an example for plant species in Europe. Regional Environmental Change 11(1):143-150.

Andrade PA, Herrera FB, Cazzola GR (Eds.) (2010). Building resilience to climate change: ecosystem-based adaptation and lessons from the field. Gland, Switzerland: IUCN.

APNB - Administrația Parcului Natural Bucegi (2011). Plan de management. Retrieved 2012 June 12 from www.bucegipark.ro/docs/Plan_de_management.pdf

Araújo MB, Alagador D, Cabeza M, Nogués-Bravo D, Thuiller W (2011). Climate change threatens European conservation areas. Ecology Letters 14(5):484-492.

Barros C, Thuiller W, Münkemüller T (2018). Drought effects on the stability of forest-grassland ecotoned under gradual climate change. PLoS ONE 13(10):e0206138.

Bazzaz FA (1996). Plants in changing environments: linking physiological, population and community ecology. Cambridge University Press, Cambridge.

Beniston M (2003). Climatic change in mountain regions: a review of possible impacts. Climatic Change 59:5-31.

Bilz M, Kell SP, Maxted N, Lansdown RV (2011). European red list of vascular plants. Luxembourg: Publications Office of the European Union.

Burrows CJ (1990). Processes of vegetation change. Unwin Hyman Publishing, London.

Campbell A, Kapos V, Scharlemann JPW, Bubb P, Chenery A, Coad L, ..., Rashid M (2009). Review of the literature on the links between biodiversity of climate change: impacts, adaptation and mitigation. Secretariat of the Convention on Biological Diversity, Montreal, Technical Series No. 42.

Ciocârlan V (2009). Flora ilustrată a României: Pteridophyta şi Spermatophyta [Illustrated flora of Romania: Pteridophyta and Spermatophyta]. Editura Ceres, Bucureşti.

Cleland EE, Chiariello NR, Loarie SR, Mooney HA, Field CB (2006). Diverse responses of phenology to global changes in a grassland ecosystem. Processing of the National Academy of Sciences 103:13740-13744.

Corlett RT, Westcatt DA (2013). Will plant movements keep up with climate change? Trends in Ecology and Evaluation. 28:482-488.

Council of Europe (1979). Convention on the conservation of European wildlife and natural heritage. Appendix I. Bern, Switzerland Bern Convention. Retrieved 2015 October 31 from http://conventions.coe.int/Treaty/FR/Treaties/Html/104-1.htm. 
Council of Europe (1992). Council Directive 92/43/EEC on the conservation of natural habitats and of wild fauna and flora. $\begin{array}{llllll}\text { Habitat } & \text { Directive. } & \text { Retrieved } & 2015 & \text { October } & 31\end{array}$ http://ec.europa.eu/environment/nature/legislation/habitatsdirective/index_en.htm

Doniță N, Popescu A, Paucă-Comănescu M, Mihăilescu S, Biriş IA (2005). Habitatele din România [Habitats of Romania]. Editura Tehnică Silvică, Bucureşti.

Dullinger S, Willner W, Plutzar C, Englisch T, Schratt-Ehrendorfer L, Moser D, ... Niklfeld H (2012). Post-glacial migration lag restricts range filling of plants in the European Alps. Global Ecology and Biogeography 21:829-840.

EEA (2012). European Environment Agency - climate change, impacts and vulnerability in Europe. EEA, Copenhagen. Retrieved 2012 June 19 from http://www.eea.europa.eu/publications/climate-impacts-and-vulnerability-2012

Engler R, Randin CF, Thuiller W, Dullinger S, Zimmermann NE, Araújo MB, ..., Guisan A (2011).21st century climate change threatens mountain flora unequally across Europe. Global Change Biology 17:2330-2341.

Erschbamer B, Kiebacher T, Mallaun M, Unterluggauer P (2009). Short-term signal of climate change along an altitudinal gradient in the South Alps. Plant Ecology 202:78-89.

Förster M, Zebisch M, Wagner-Lücker I, Sschmidt T, Renner K, Neubert M (2014). Remote sensing-based monitoring of potential climate-induce impacts on habitats. In: Rannow S, Neubert M (eds). Managing protected areas in Central and Eastern Europe under climate change. Springer Science + Business, Dordrecht pp 95-113.

Frischbierr N, Profft I, Hagemann U (2014). Potential impact of climate change on forest habitats in the biosphere reserve Vessertal-Thuringian Forest in Germany. In: Rannow S, Neubert M (Eds). Managing protected areas in Central and Eastern Europe under climate change. Springer Science + Business, Dordrecht pp 243-257.

Gafta D, Mountford O (coord.) (2008). Manualul de interpretare a habitatelor Natura 2000 din România [Manual for the interpretation of Natura 2000 habitats in Romania]. Editura Risoprint, Cluj-Napoca.

Gilliam F (2016). Forest ecosystems of temperate climatic regions: from ancient use to climate change. New Phytologist 212: 871-887.

Gottffried M, Pauli H. Reiter K, Grabherrr G (1999). A fine-scaled predictive model for changes in species distribution patterns of high mountain plants induces by climatic warming. Diversity and Distributions 5:241-251.

Gottfried M, Pauli H, Futschik A (2012). Continent-wide response of mountain vegetation to climate change. Nature Climate Change 2:111-115.

Grabherr G, Gottfried M, Pauli H (1994). Climate effects on mountain plants. Nature 369:448.

Gray SB, Brady SM (2016). Plant developmental responses to climate change. Developmental Biology 419(1):64-77.

Grimm NB, Chapin III FS, Bierwagen B, Gonzalez P, Groffman PM, Luo Y, ... Williamson CE (2013). The impacts of climate change on ecosystem structure and function. Frontiers in Ecology and the Environment 11(9):474-482.

Hellmann JJ, Byers JE, Bierwagen BG, Dukes JS (2008). Five potential consequences of climate change for invasive species. Conservation Biology 22(3):534-543.

IPCC (2007). Intergovernmental Panel on Climate Change summary for policy makers. In: Parry ML, Canziani OF, Palutikof JP, van der Linden PJ, Hanson CE (Eds). Climate change 2007: Impacts, adaptation and vulnerability. Contribution of Working Group II to the Fourth Assessment Report of the Intergovernmental Panel on Climate Change (IPCC). Cambridge University Press, Cambridge, UK.

Inouye DW (2019). Effects of climate change on alpine plants and their pollinators. Annals of the New York Academy of Sciences. https://doi.org/10.1111/nyas. 14104

Klanderud K, Totland $\varnothing ~(2005)$. Simulated climate change altered dominance hierarchies and diversity of an alpine biodiversity hotspot. Ecology 86(8):2047-2054.

Körner C (1999). Alpine Plant Life. Springer-Verlag, Heidelberg and New York.

Kullman L (2007). Tree line population monitoring of Pinus sylvestris in the Swedish Scandes, 1973-2005: implications for tree line theory and climate change ecology. Journal of Ecology 95:41-52.

Lapenis A, Shvidenko A, Shepaschenko D, Nilson S, Aiyyer A (2005). Acclimation of Russian forests to recent changes in climate. Global Change Biology 11:2090-2102.

Lesica P, McCune B (2004). Decline of arctic-alpine plants at the southern margin of their range following a decade of climatic warming. Journal of Vegetation Science 15:679-690.

Lindner M, Maroschek M, Netherer S (2010). Climate change impacts, adaptive capacity and vulnerability of European forest ecosystems. Forest Ecology and Management 259:698-709. 
Sârbu A et al. (2020). Not Bot Horti Agrobo 48(1):456-479.

478

Matteodo M, Ammann K, Verrecchia EP, Vittoz P (2016). Snowbeds are more affected than other subalpine-alpine plant communities by climate change in the Swiss Alps. Ecology and Evolution 6(19):6969-6982.

Mountford O, Gafta D, Anastasiu P, Bărbos M, Nicolin A, Niculescu M, Oprea A (2008). Natura 2000 in Romania. Habitat factsheets. Ministry of Environment and Sustainable Development, Bucureşti.

Oltean M, Negrean G, Popescu A, Roman N, Dihoru G, Sanda V, Mihăilescu S (1994). Lista roşie a plantelor superioare din România [Red list of superior plants from Romania]. In Oltean M (coord.). Studii, sinteze, documentaţii de ecologie, Acad. Română, Institutul de Biologie 1:1-52.

Ozenda P, Borel J-L (1991). Les conséquences écologiques possibles des changements climatiques dans l'Arc alpin. Rapport FUTURALP 1, Centre International pour l'Environnement Alpin (ICALPE), Chambéry.

Pauli H, Gottfried M, Grabherr G (1996). Effects of climate change on mountain ecosystems. Upward Shifting of Alpine Plants'. World Resources Review 8(3):382-390.

Pauli H, Gottfried M, Grabherr G (2003). Effects of climate change on the alpine and nival vegetation of the Alps. Journal of Mountain Ecology 7:9-12.

Pauli H, Gottfried, M, Reiter K, Klettner C, Grabherr G (2007). Signals of range expansions and contractions of vascular plants in the high Alps: observations (1994-2004) at the GLORIA master site Schrankogel, Tyrol, Austria. Global Change Biology 13:147-156.

Petermann J, Alzer S, Ellwanger G, Schöder E, Ssymank A (2007). Klimawandel - Herausforderung für das europaweite Schutzgebietssystem Natura 2000 [Climate change - a challenge for the European Natura 2000 protected area system]. Naturschutz und Biologische Vielfalt 46:127-148.

Popescu A, Sanda V (1998) Conspectul florei cormofitelor spontane din România [The conspectus of spontaneous cormophytes flora from Romania]. Acta Botanica Horti Bucurestiensis / 1998/:3-336.

Puşcaru D, Puşcaru-Soroceanu E, Paucă A, Şerbănescu I, Beldie A, Ştefureac T, ..., Taşcenco V (1956). Păşunile alpine din Munții Bucegi [Alpine pastures from Bucegi Mountains]. Editura Academiei Române, Bucureşti.

Sârbu A (2011). HABIT-CHANGE project. Report on actual habitat types and potential conflicts - Natural Park Bucegi. Output 3.1.9. Retrieved 2016 August 14 from http://www2.ioer.de/download/habit-change/HABITCHANGE_3_1_9_habitat_types_and_potential_conflicts_BucNP_pdf

Sârbu A, Anastasiu P, Smarandache D, Pascale G, Lițescu S, Mihai DC (2013). Habitats with conservation value from Bucegi Natural Park. Editura Ceres, Bucureşti.

Sârbu A, Janauer G, Profft I, Kaligarič M, Doroftei M (2014). potential impacts of climate change on protected habitats. In: Rannow S, Neubert M (Eds). Managing protected areas in Central and Eastern Europe under climate change. Springer Science + Business media, Dordrecht, Heidelberg New York, London pp 45-59.

Sârbu A, Anastasiu P, Smarandache D (2014). Potential impacts of climate change on alpine habitats from Bucegi Natural Park, Romania. In: Rannow S, Neubert M (Eds). Managing protected areas in Central and Eastern Europe under climate change. Springer Science + Business media, Dordrecht, Heidelberg New York, London pp 259-267.

Sârbu I, Nicolae S, Oprea A (2013). Plante vasculare din România: Determinator ilustrat de teren [Vascular plants from Romania. Field illustrated determinator]. Editura Victor B Victor, Bucureşti.

Săvulescu T (Ed.) (1952-1976). Flora României [Romanian Flora]. Vols. I-XIII. Editura Academiei Române, Bucureşti.

Schöb C, Kammer PM, Choler P, Veit H (2008). Small-scale plant species distribution in snowbeds and its sensitivity to climate change. Plant Ecology 200:91-94.

Stagl J, Hattermann F (2011). HABIT-CHANGE project. Climate change impacts as boundary condition and hydrological features. Outputs 3.2.3. 3.2.7. Retrieved 2016 August 05 from http://www2.ioer.de/download/habit-change/HABITCHANGE_3_2_3+3_2_7_climate_trends\%20and\%20impacts\%20on\%20hydrological\%20features.pdf

Stanisci A, Frate L, Morra di Cella U, Pelino G, Petey M, Simiscalco C, Carranza ML (2016). Short-term signals of climate change in Italian summit vegetation: observation at two GLORIA sites. Plant Biosystems 150(2):227-235.

The Plant List (2013). Version 1.1. Published on the Internet. Retrieved 2015 January 23 from www.theplantlist.org

Theurillat JP, Felber F, Geissler P, Gobat JM, Fierz M, Fischlin A, ... Zhao G-F (1998). Sensitivity of plant and soils ecosystems of the Alps to climate change. In: Cebon P, Dahinden U, Davies HC, Imboden D, Jaeger CC (Eds). Views from the Alps: regional perspectives on climate change. MIT Press Cambridge, MA pp 225-308.

Theurillat JP, Guisan A (2001). Potential impact of climate change on vegetation in the European Alp: a review. Climatic Change 50:77-109. 
Tuiller W, Lavorel S, Araújo MB, Sykes MT, Prentice IC (2005). Climate change threats to plant diversity in Europe. Proceedings of the National Academy of Sciences of the United States of America 102(23):8245-8250.

Vitasse Y, François C, Delpierre E, Kremer A, Chuine I, Delzon S (2011). Assessing the effects of climate change on the phenology of European temperature trees. Agricultural and Forest Meteorology 151(7):969-980.

Wagner-Lücker I (2012). HABIT-CHANGE project. Sensitivity and potential impact maps. Combined Report on 4.3.5.4.6.1. and 4.6.2. Retrieved 2016 September 16 from http://www2.ioer.de/download/habit-change/HABITCHANGE_4_3_5+4_6_1+4_6_2_Report\%20Sensitivity+Potential_Impact_Maps.pdf

Wagner-Lücker I, Förster M, Janauer G (2014). Assessment of climate-induced impacts on habitats. In: Rannow S, Neubert M (Eds). Managing protected areas in Central and Eastern Europe under climate change. Springer Science + Business media, Dordrecht, Heidelberg New York, London pp 115-134.

Walther G-R, Beißner S, Burga CA (2005). Trends in the upward shift of alpine plants. Journal of Vegetation Science 16:541548.

Zhang J, Nielsen SE, Chen Y, Georges D, Qin Y, Wang S-S, Svenning J-C, Thuiller W (2016). Extinction risk of North American seed plants elevated by climate and land-use change. Journal of Applied Ecology 54:303-312.
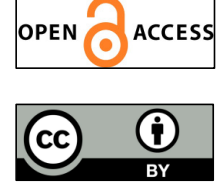

The journal offers free, immediate, and unrestricted access to peer-reviewed research and scholarly work. Users are allowed to read, download, copy, distribute, print, search, or link to the full texts of the articles, or use them for any other lawful purpose, without asking prior permission from the publisher or the author.

License - Articles published in Notulae Botanicae Horti Agrobotanici Cluj-Napoca are Open-Access, distributed under the terms and conditions of the Creative Commons Attribution (CC BY 4.0) License. (c) Articles by the authors; UASVM, Cluj-Napoca, Romania. The journal allows the author(s) to hold the copyright/to retain publishing rights without restriction. 


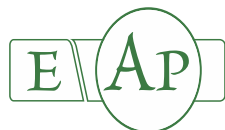

AcademicPres
Sârbu A et al. (2020)

Notulae Botanicae Horti Agrobotanici Cluj-Napoca 48(1):456-479

DOI: $10.15835 /$ nbha48111756

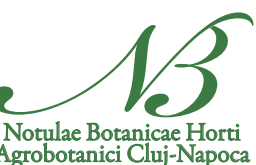

Notulae Botanicae Horti

Annex 1. The list of rare species, endemic and/or endangered, of Natura 2000 site Bucegi: distribution and ecological preferences (humidity and temperature)

\begin{tabular}{|c|c|c|c|c|c|c|c|c|c|}
\hline \multirow{2}{*}{ Nr. } & \multirow{2}{*}{ Taxon } & \multirow{2}{*}{$\begin{array}{c}\text { IUCN } \\
\text { Red } \\
\text { List } \\
2011 \\
\end{array}$} & \multirow{2}{*}{$\begin{array}{c}\text { Habitat } \\
\text { Directive } \\
\text { Annexes }\end{array}$} & \multirow{2}{*}{$\begin{array}{c}\text { Bern } \\
\text { Convention } \\
\text { Annexes }\end{array}$} & \multirow{2}{*}{$\begin{array}{l}\text { CITES } \\
\text { Annexes }\end{array}$} & \multirow{2}{*}{$\begin{array}{c}\text { Romanian } \\
\text { Red List } \\
\text { (Oltean } \text { et al., } \\
1994)\end{array}$} & \multirow{2}{*}{$\begin{array}{l}\text { Distribution } \\
\text { (cf Sârbu et } \\
\text { al., 2013) }\end{array}$} & \multicolumn{2}{|r|}{ Ecological preferences } \\
\hline & & & & & & & & Humidity & Temperature \\
\hline 1 & $\begin{array}{l}\text { Acbillea oxyloba (DC.) Sch.Bip. subsp. schurii (Sch.Bip.) } \\
\text { Heimerl [syn. Acbillea schurii] }\end{array}$ & - & - & - & - & $\mathrm{R}$ & $\begin{array}{l}\text { Carp. orient. } \\
\& \text { merid. }\end{array}$ & $\begin{array}{l}\text { mesophyte - } \\
\text { mesohygrophyte }\end{array}$ & microthermophyte \\
\hline 2 & Aconitum toxicum Rchb. & - & - & - & - & - & Carp.-Balc. & mesohygrophyte & microthermophyte - mesothermophyte \\
\hline 3 & $\begin{array}{l}\text { Aconitum vulparia subsp. lasianthum [accepted name } \\
\text { Aconitum vulparia } \text { Rchb.] }\end{array}$ & - & - & - & - & - & $\begin{array}{lr}\text { Eur. } & \text { Centr. } \\
\& & \text { West } \\
\text { Carp. } & \\
\end{array}$ & mesohygrophyte & microthermophyte - mesothermophyte \\
\hline 4 & Alyssum repens Baumg. & - & - & - & - & - & Carp.-Balc. & euriphyte & eurithermophyte \\
\hline 5 & $\begin{array}{l}\text { Anacamptis coriophora (L.) R.M.Bateman, Pridgeon \& } \\
\text { M.W.Chase [syn. Orchis coriophora] }\end{array}$ & LC & - & - & II & $\mathrm{R}$ & Centr. Eur. & $\begin{array}{l}\text { mesophyte - } \\
\text { mesohygrophyte }\end{array}$ & eurithermophyte \\
\hline 6 & $\begin{array}{l}\text { Anacamptis laxiflora (Lam.) R.M.Bateman, Pridgeon \& } \\
\text { M.W.Chase }\end{array}$ & LC & - & - & II & $\mathrm{R}$ & Pont.-Pan. & mesohygrophyte & mesothermophyte \\
\hline 7 & $\begin{array}{l}\text { Anacamptis morio (L.) R.M.Bateman, Pridgeon \& } \\
\text { M.W.Chase [syn. Orchismorio] }\end{array}$ & NT & - & - & II & $\mathrm{R}$ & Eur. & $\begin{array}{l}\text { xeromesophyte - } \\
\text { mesophyte }\end{array}$ & mesothermophyte \\
\hline 8 & Anacamptis pyramidalis (L.) Rich. & - & - & - & - & $\mathrm{V} / \mathrm{R}$ & $\begin{array}{l}\text { Centr. Eur. - } \\
\text { Submed.-Atl. }\end{array}$ & $\begin{array}{l}\text { xerophyte - } \\
\text { xeromesophyte }\end{array}$ & mesothermophyte \\
\hline 9 & Androsace chamaejasme Wulfen & - & - & - & - & $\mathrm{V} / \mathrm{R}$ & $\begin{array}{l}\text { Circ. arct.- } \\
\text { alp. }\end{array}$ & mesophyte & hekistothermophyte - psichrothermophyte \\
\hline 10 & Androsace obtusifolia All. & - & - & - & - & $\mathrm{R}$ & Alp.-Carp. & $\begin{array}{l}\text { mesophyte - } \\
\text { mesohygrophyte }\end{array}$ & hekistothermophyte \\
\hline 11 & $\begin{array}{l}\text { Androsace villosa L. var. arachnoidea (Schott, Nyman \& } \\
\text { Kotschy) R.Knuth }\end{array}$ & - & - & - & - & $\mathrm{R}$ & $\begin{array}{l}\text { Carp. orient. } \\
\& \text { merid. }\end{array}$ & xeromesophyte & psichrothermophyte \\
\hline
\end{tabular}


Sârbu A et al. (2020). Not Bot Horti Agrobo 48(1):456-479.

\begin{tabular}{|c|c|c|c|c|c|c|c|c|c|}
\hline 12 & $\begin{array}{l}\text { Anemone transsilvanica (Fuss) Heuff. [syn. Hepatica } \\
\text { transsilvanica] }\end{array}$ & - & - & - & - & $\mathrm{nt}$ & $\begin{array}{l}\text { Carp. } \\
\text { (Romania) }\end{array}$ & mesophyte & microthermophyte \\
\hline 13 & Angelica archangelica $\mathrm{L}$. & - & - & - & - & $\mathrm{V}$ & Euras. bor. & $\begin{array}{l}\text { mesohygrophyte } \\
\text { - hygrophyte }\end{array}$ & microthermophyte - mesothermophytc \\
\hline 14 & $\begin{array}{l}\text { Anthemis carpatica Waldst. \& Kit. ex Willd. subsp. } \\
\text { pyrethriformis (Schur) Beldie }\end{array}$ & - & - & - & - & $\mathrm{R}$ & Carp. & xeromesophyte & psichrothermophyte \\
\hline 15 & Aquilegia nigricans Baumg. subsp. subscaposa (Borbás) Soó & - & - & - & - & $\mathrm{R}$ & $\begin{array}{l}\text { Carp. } \\
\text { (Romania) }\end{array}$ & $\begin{array}{l}\text { xeromesophyte - } \\
\text { mesophyte }\end{array}$ & microthermophyte \\
\hline 16 & Aquilegia transsilvanica Schur & - & - & - & - & $\mathrm{R}$ & Carp. & $\begin{array}{l}\text { xeromesophyte - } \\
\text { mesophyte }\end{array}$ & microthermophyte \\
\hline 17 & Armeria alpina (DC.) Willd. & - & - & - & - & $\mathrm{R}$ & Alp.-Carp. & $\begin{array}{l}\text { mesophyte - } \\
\text { mesohygrophyte }\end{array}$ & eurithermophyte \\
\hline 18 & Arnica montana $\mathrm{L}$. & LC & $\mathrm{V}$ & - & - & $\mathrm{V}$ & Eur. (mont.) & mesophyte & microthermophyte - mesothermophytc \\
\hline 19 & Astragalus alpinus $\mathrm{L}$. & - & - & - & - & $\mathrm{R}$ & $\begin{array}{l}\text { Euras. arct.- } \\
\text { alp. }\end{array}$ & $\begin{array}{l}\text { xeromesophyte - } \\
\text { mesophyte }\end{array}$ & hekistothermophyte \\
\hline 20 & Astragalus australis (L.) Lam. var. bucsescii (Jav.) Gusul. & - & - & - & - & $\mathrm{R}$ & $\begin{array}{l}\text { Carp. } \\
\text { (Romania) }\end{array}$ & mesophyte & hekistothermophyte \\
\hline 21 & $\begin{array}{l}\text { Athamanta turbith (L.) Brot. subsp. hungarica (Borbás) } \\
\text { Tutin }\end{array}$ & - & - & - & - & $\mathrm{R}$ & Carp. merid. & xeromesophyte & mesothermophyte \\
\hline 22 & Bupleurum ranunculoides $\mathrm{L}$. & - & - & - & - & $\mathrm{R}$ & Alp. Eur. & mesophyte & hekistothermophyte \\
\hline 23 & Campanula carpatica Jacq. & - & - & - & - & $\mathrm{R}$ & $\begin{array}{l}\text { Carp. orient. } \\
\& \text { merid. }\end{array}$ & mesophyte & microthermophyte - mesothermophytc \\
\hline 24 & $\begin{array}{l}\text { Campanula patula L. subsp. abietina (Griseb. \& Schenk) } \\
\text { Simonk. }\end{array}$ & DD & - & I & - & - & Carp.-Balc. & $\begin{array}{l}\text { mesophyte - } \\
\text { mesohygrophyte }\end{array}$ & microthermophyte \\
\hline 25 & Campanula serrata (Kit. ex Schult.) Hendrych & LC & $\mathrm{II} / \mathrm{IV}$ & - & - & - & Carp. & mesophyte & microthermophyte - mesothermophytc \\
\hline 26 & Campanula transsilvanica Schur ex André & - & - & - & - & $\mathrm{V} / \mathrm{R}$ & Carp.-Balc. & mesophyte & microthermophyte \\
\hline 27 & $\begin{array}{l}\text { Cardamine glanduligera O.Schwarz }[\text { syn. Dentaria } \\
\text { glandulosa }]\end{array}$ & - & - & - & - & - & Carp. & mesohygrophyte & microthermophyte - mesothermophytc \\
\hline 28 & Cardaminopsis neglecta (Schult.) Hayek & - & - & - & - & $\mathrm{R}$ & Carp. & $\begin{array}{l}\text { mesophyte } \\
\text { mesohygrophyte }\end{array}$ & psichrothermophyte \\
\hline
\end{tabular}


Sârbu Aet al. (2020). Not Bot Horti Agrobo 48(1):456-479.

\begin{tabular}{|c|c|c|c|c|c|c|c|c|c|}
\hline 29 & Carduus kerneri Simonk. & - & - & - & - & - & Carp--Balc. & $\begin{array}{l}\text { xeromesophyte - } \\
\text { mesophyte }\end{array}$ & microthermophyte \\
\hline 30 & Carex brachystachys Schrank & - & - & - & - & $\mathrm{R}$ & $\begin{array}{l}\text { Pirinei - Alpi } \\
\text { - Apennine- } \\
\text { N-W Balc.- } \\
\text { Carp. }\end{array}$ & mesohygrophyte & microthermophyte \\
\hline 31 & Carex capillaris $\mathrm{L}$. & - & - & - & - & $\mathrm{R}$ & $\begin{array}{l}\text { Circ. arct.- } \\
\text { alp. }\end{array}$ & mesophyte & psichrothermophyte \\
\hline 32 & Carex chordorrbiza L.f. & - & - & - & - & $\mathrm{R}$ & Circ. bor. & hygrophyte & microthermophyte - mesothermophyte \\
\hline 33 & Carex fuliginosa Schkuhr & - & - & - & - & $\mathrm{R}$ & $\begin{array}{l}\text { Euras. arct.- } \\
\text { alp. eur. }\end{array}$ & mesophyte & hekistothermophyte - psichrothermophyte \\
\hline 34 & Carex rupestris All. & - & - & - & - & $\mathrm{R}$ & $\begin{array}{l}\text { Circ. arct.- } \\
\text { alp. }\end{array}$ & $\begin{array}{l}\text { xeromesophyte - } \\
\text { mesophyte }\end{array}$ & psichrothermophyte \\
\hline 35 & Centaurea kotschyana Heuff. & - & - & - & - & $\mathrm{R}$ & Carp-balc. & xeromesophyte & subthermophyte \\
\hline 36 & $\begin{array}{l}\text { Centaurea phrygia L. subsp. melanocalatbia (Borbás) } \\
\text { Dostál }\end{array}$ & - & - & - & - & $\mathrm{R}$ & Carp. & mesophyte & microthermophyte - mesothermophyte \\
\hline 37 & $\begin{array}{l}\text { Centaurea pinnatifida Schur [syn. Cyanus pinnatifidus } \\
\text { (Schur) Holub] }\end{array}$ & - & - & - & - & $\mathrm{R}$ & Carp. & xeromesophyte & mesothermophyte \\
\hline 38 & Cephalanthera damasonium (Mill.) Druce & LC & - & - & II & $\mathrm{nt}$ & Eur. & mesophyte & mesothermophyte \\
\hline 39 & Cephalanthera longifolia (L.) Fritsch & LC & - & - & II & $\mathrm{nt}$ & Eur. & mesophyte & mesothermophyte \\
\hline 40 & Cephalanthera rubra (L.) Rich. & LC & - & - & II & $\mathrm{R}$ & Eur. & mesophyte & mesothermophyte \\
\hline 41 & $\begin{array}{l}\text { Cerastium arvense L. subsp. lerchenfeldianum (Schur) } \\
\text { Asch. \& Graebn. }\end{array}$ & - & - & - & - & $\mathrm{R}$ & $\begin{array}{l}\text { Carp. orient. } \\
\& \quad \text { merid.; } \\
\text { Jug. }\end{array}$ & $\begin{array}{l}\text { xeromesophyte - } \\
\text { mesophyte }\end{array}$ & eurithermophyte \\
\hline 42 & Cerastium transsilvanicum Schur & - & - & - & - & $\mathrm{R}$ & $\begin{array}{l}\text { Carp. orient. } \\
\& \text { merid. }\end{array}$ & mesophyte & psichrothermophyte \\
\hline 43 & Chamorchis alpina (L.) Rich. & $\mathrm{LC}$ & - & - & II & $\mathrm{R}$ & $\begin{array}{l}\text { Euras. arct.- } \\
\text { alp. eur. }\end{array}$ & $\begin{array}{l}\text { xeromesophyte - } \\
\text { mesophyte }\end{array}$ & psichrothermophyte \\
\hline 44 & Conioselinum vaginatum (Spreng.) Thell. & - & - & - & - & $\mathrm{R}$ & Euras. bor. & mesophyte & microthermophyte \\
\hline 45 & Crepis conyzifolia (Gouan) A.Kern. & - & - & - & - & $\mathrm{R}$ & Alp. Eur. & mesophyte & microthermophyte \\
\hline 46 & Crocus banaticus J.Gay & - & - & - & - & - & Carp. & mesophyte & mesothermophyte \\
\hline 47 & Dactylorbiza cordigera (Fr.) Soó & LC & - & - & II & $\mathrm{R}$ & Carp.-Balc. & mesohygrophyte & microthermophyte \\
\hline 48 & Dactylorbiza fuchsii (Druce) Soó & LC & - & - & II & $\mathrm{R}$ & Euras. & mesophyte & eurithermophyte \\
\hline
\end{tabular}


Sârbu Aet al. (2020). Not Bot Horti Agrobo 48(1):456-479.

\begin{tabular}{|c|c|c|c|c|c|c|c|c|c|}
\hline 49 & Dactylorbiza incarnata (L.) Soó & LC & - & - & II & $\mathrm{R}$ & Euras. & mesohygrophyte & mesothermophyte \\
\hline 50 & Dactylorbiza maculata (L.) Soó & LC & - & - & II & $\mathrm{R}$ & Eur. & mesohygrophyte & microthermophyte \\
\hline 51 & Dactylorbiza sambucina (L.) Soó & LC & - & - & II & $\mathrm{R}$ & Eur. & mesophyte & microthermophyte \\
\hline 52 & Daphne blagayana Freyer & - & - & - & - & $\mathrm{V} / \mathrm{R}$ & $\begin{array}{l}\text { Alp.-Carp.- } \\
\text { Balc. }\end{array}$ & $\begin{array}{l}\text { mesophyte - } \\
\text { mesohygrophyte }\end{array}$ & mesothermophyte \\
\hline 53 & $\begin{array}{l}\text { Dianthus carthusianorum L. subsp. tenuifolius (Schur) } \\
\text { Hegi [syn. Dianthus tenuifolius] }\end{array}$ & - & - & - & - & $\mathrm{nt}$ & Carp. & xeromesophyte & mesothermophyte \\
\hline 54 & $\begin{array}{l}\text { Dianthus glacialis Haenke subsp. gelidus (Schott, Nyman } \\
\text { \& Kotschy) Tutin }\end{array}$ & - & - & - & - & $\mathrm{R}$ & $\begin{array}{l}\text { Carp. orient. } \\
\& \text { merid. }\end{array}$ & $\begin{array}{l}\text { mesophyte - } \\
\text { mesohygrophyte }\end{array}$ & hekistothermophyte \\
\hline 55 & Dianthus spiculifolius Schur & - & - & - & - & $\mathrm{R}$ & Carp. & xeromesophyte & mesothermophyte - submesothermophyte \\
\hline 56 & Doronicum carpaticum (Griseb. \& Schenk) Nyman & - & - & - & - & $\mathrm{R}$ & Alp. Eur. & mesohygrophyte & psichrothermophyte \\
\hline 57 & Draba aizoides L. subsp. zmudae Zapal. & - & - & - & - & $\mathrm{R}$ & Carp. & xeromesophyte & eurithermophyte \\
\hline 58 & Draba compacta Schott, Nyman \& Kotschy & - & - & - & - & $\mathrm{R}$ & Carp.-Balc. & xeromesophyte & psichrothermophyte \\
\hline 59 & Draba dorneri Heuff. & DD & II/IV & $\mathrm{I}$ & - & $\mathrm{V} / \mathrm{R}$ & Dacic & xeromesophyte & psichrothermophyte \\
\hline 60 & Drabafladnitzensis Wulfen & - & - & - & - & $\mathrm{R}$ & Circ. Bor. & xeromesophyte & microthermophyte - mesothermophyte \\
\hline 61 & Draba haynaldii Stur & - & - & - & - & $\mathrm{V} / \mathrm{R}$ & $\begin{array}{l}\text { Carp. orient. } \\
\& \text { merid. }\end{array}$ & xeromesophyte & psichrothermophyte \\
\hline 62 & Drabakotschyi Stur & - & - & - & - & nt & $\begin{array}{l}\text { Carp. orient. } \\
\& \text { merid. }\end{array}$ & xeromesophyte & psichrothermophyte \\
\hline 63 & Epilobium alpestre (Jacq.) Krock. & - & - & - & - & $\mathrm{R}$ & Alp. eur. & mesohygrophyte & microthermophyte \\
\hline 64 & Epilobium alsinifolium Vill. & - & - & - & - & $\mathrm{R}$ & $\begin{array}{l}\text { Arct.-Alp.- } \\
\text { Eur. }\end{array}$ & hygrophyte & psichrothermophyte \\
\hline 65 & Epilobium anagallidifolium Lam. & - & - & - & - & $\mathrm{R}$ & $\begin{array}{l}\text { Circ. arct.- } \\
\text { alp. }\end{array}$ & $\begin{array}{l}\text { mesohygrophyte } \\
\text { - hygrophyte }\end{array}$ & psichrothermophyte \\
\hline 66 & Epipactis atrorubens (Hoffm.) Besser & LC & - & - & II & $\mathrm{R}$ & Euras. & $\begin{array}{l}\text { xeromesophyte - } \\
\text { mesophyte }\end{array}$ & eurithermophyte \\
\hline 67 & Epipactis helleborine (L.) Crantz & LC & - & - & II & $\mathrm{R}$ & Euras. & mesophyte & mesothermophyte \\
\hline 68 & Epipactis microphylla (Ehrh.) Sw. & NT & - & - & II & $\mathrm{R}$ & $\begin{array}{l}\text { Centr. Eur.- } \\
\text { Medit. }\end{array}$ & mesophyte & mesothermophyte \\
\hline 69 & Epipactis purpurata Sm. & LC & - & - & II & $\mathrm{R}$ & $\begin{array}{l}\text { Centr. Eur.- } \\
\text { Subatl. }\end{array}$ & mesophyte & mesothermophyte \\
\hline
\end{tabular}


Sârbu Aet al. (2020). Not Bot Horti Agrobo 48(1):456-479.

\begin{tabular}{|c|c|c|c|c|c|c|c|c|c|}
\hline 70 & Epipogium aphyllum $\mathrm{Sw}$. & LC & - & - & II & $\mathrm{R}$ & Euras. & mesophyte & microthermophyte - mesothermophyte \\
\hline 71 & Erigeron alpinus $\mathrm{L}$. & - & - & - & - & $\mathrm{R}$ & Euras. alp. & mesophyte & hekistothermophyte \\
\hline 72 & Erigeron atticus Vill. & - & - & - & - & $\mathrm{R}$ & Alp. Eur. & $\begin{array}{l}\text { xeromesophyte - } \\
\text { mesophyte }\end{array}$ & psichrothermophyte \\
\hline 73 & Erigeron nanus Nutt. & - & - & - & - & $\mathrm{V} / \mathrm{R}$ & Carp. & mesophyte & hekistothermophyte \\
\hline 74 & Erigeron uniflorus $\mathrm{L}$. & - & - & - & - & $\mathrm{R}$ & $\begin{array}{l}\text { Circ. arct.- } \\
\text { alp. }\end{array}$ & mesophyte & hekistothermophyte - psichrothermophyte \\
\hline 75 & Eriophorum angustifolium Honck. & LC & - & - & - & - & Circ. & hygrophyte & mesothermophyte \\
\hline 76 & Eriophorum scheuchzeri Hoppe & LC & - & - & - & $\mathrm{R}$ & $\begin{array}{l}\text { Circ. arct.- } \\
\text { alp. Eur. }\end{array}$ & hygrophyte & psichrothermophyte \\
\hline 77 & Eritrichium nanum (L.) Schrad. ex Gaudin s.l. & - & - & - & - & $\mathrm{R}$ & Alp--Carp. & xeromesophyte & hekistothermophyte - psichrothermophyte \\
\hline 78 & $\begin{array}{l}\text { Erysimum witmannii Zaw. subsp. transsilvanicum P.W. } \\
\text { Ball }\end{array}$ & - & - & - & - & $\mathrm{R}$ & Carp. merid. & xeromesophyte & mesothermophyte \\
\hline 79 & Festuca amethystina $\mathrm{L}$. & - & - & - & - & $\mathrm{R}$ & $\begin{array}{l}\text { Alp.-Centr. } \\
\text { Eur. }\end{array}$ & mesophyte & mesothermophyte \\
\hline 80 & Festuca bucegiensis Markgr.-Dann. & - & - & - & - & $\mathrm{R}$ & Carp. merid. & xeromesophyte & hekistothermophyte \\
\hline 81 & Festuca carpathica F.Dietr. & - & - & - & - & $\mathrm{R}$ & $\begin{array}{l}\text { Carp. orient. } \\
\& \text { merid. }\end{array}$ & mesophyte & microthermophyte \\
\hline 82 & Festuca versicolor Tausch & - & - & - & - & $\mathrm{R}$ & Carp. & xeromesophyte & subthermophyte \\
\hline 83 & Galanthus nivalis $\mathrm{L}$. & NT & $\mathrm{V}$ & - & II & nt & $\begin{array}{l}\text { Centr. Eur. - } \\
\text { Submed. }\end{array}$ & mesophyte & mesothermophyte \\
\hline 84 & Gentiana acaulis $\mathrm{L}$. & - & - & - & - & $\mathrm{R}$ & Alp. Eur. & mesophyte & microthermophyte \\
\hline 85 & Gentiana frigida Haenke & - & - & - & - & $\mathrm{R}$ & Alp.-Carp. & mesophyte & hekistothermophyte \\
\hline 86 & Gentiana lutea $\mathrm{L}$. & LC & $\mathrm{V}$ & - & - & $\mathrm{V} / \mathrm{R}$ & Alp. Eur. & mesophyte & microthermophyte \\
\hline 87 & Gentiana punctata $\mathrm{L}$. & - & - & - & - & $\mathrm{R}$ & Alp. Eur. & mesophyte & microthermophyte \\
\hline 88 & Gentianella bulgarica (Velen.) Holub & - & - & - & - & $\mathrm{R}$ & Carp.-Balc. & $\begin{array}{l}\text { xeromesophyte - } \\
\text { mesophyte }\end{array}$ & mesothermophyte \\
\hline 89 & $\begin{array}{l}\text { Geranium caeruleatum Schur [syn. Geranium sylvaticum } \\
\text { subsp. caeruleatum } \text { ] }\end{array}$ & - & - & - & - & $\mathrm{R}$ & Carp.-Balc. & $\begin{array}{l}\text { mesophyte - } \\
\text { mesohygrophyte }\end{array}$ & microthermophyte - mesothermophyte \\
\hline 90 & Geum reptans $\mathrm{L}$. & - & - & - & - & $\mathrm{R}$ & Alp. Eur. & mesohygrophyte & psichrothermophyte \\
\hline 91 & Goodyera repens (L.) R.Br. & LC & - & - & II & $\mathrm{R}$ & Circ. & mesophyte & eurithermophyte \\
\hline
\end{tabular}


Sârbu Aet al. (2020). Not Bot Horti Agrobo 48(1):456-479.

\begin{tabular}{|c|c|c|c|c|c|c|c|c|c|}
\hline 92 & Gymnadenia conopsea (L.) R.Br. & $\mathrm{LC}$ & - & - & II & $\mathrm{R}$ & Eur. & $\begin{array}{l}\text { mesophyte - } \\
\text { mesohygrophyte }\end{array}$ & microthermophyte \\
\hline 93 & Gymnadenia nigra (L.) Rchb.f. [syn. Nigritella nigra] & LC & - & - & II & $\mathrm{V} / \mathrm{R}$ & $\begin{array}{l}\text { Euras. arct.- } \\
\text { alp. Eur. }\end{array}$ & mesophyte & psichrothermophyte \\
\hline 94 & Gymnadenia rubra Wettst. [syn. Nigritella rubra] & - & - & - & - & $\mathrm{V} / \mathrm{R}$ & E Alp.-Carp. & mesophyte & eurithermophyte \\
\hline 95 & Gypsophila petraea (Baumg.) Rchb. & - & - & - & - & $\mathrm{R}$ & $\begin{array}{l}\text { Carp. orient. } \\
\& \text { merid. }\end{array}$ & xeromesophyte & mesothermophyte \\
\hline 96 & Hedysarum hedysaroides (L.) Schinz \& Thell. & - & - & - & - & $\mathrm{R}$ & $\begin{array}{l}\text { Circ. arct.- } \\
\text { alp. }\end{array}$ & mesophyte & psichrothermophyte - microthermophyte \\
\hline 97 & Helictotrichon planiculme (Schrad.) Pilg. & - & - & - & - & $\mathrm{R}$ & $\begin{array}{l}\text { Carp.-Balc.- } \\
\text { Sudet. }\end{array}$ & mesophyte & microthermophyte - mesothermophyte \\
\hline 98 & Heracleum carpaticum Porc. & - & - & - & - & $\mathrm{V} / \mathrm{R}$ & Dacic & mesophyte & microthermophyte \\
\hline 99 & Heracleum palmatum Baumg. & - & - & - & - & $\mathrm{nt}$ & $\begin{array}{l}\text { Carp. } \\
\text { (Romania) }\end{array}$ & mesohygrophyte & microthermophyte - mesothermophyte \\
\hline 100 & Herminium monorchis (L.) R.Br. & DD & - & - & II & $\mathrm{R}$ & Euras. & mesophyte & mesothermophyte \\
\hline 101 & $\begin{array}{l}\text { Hesperis moniliformis Schur [syn. Hesperis matronalis } \\
\text { subsp. moniliformis] }\end{array}$ & - & - & - & - & $\mathrm{R}$ & $\begin{array}{l}\text { Carp. orient. } \\
\text { \& merid. }\end{array}$ & $\begin{array}{l}\text { xerophyte - } \\
\text { xeromesophyte }\end{array}$ & microthermophyte \\
\hline 102 & Hesperis nivea Baumg. & - & - & - & - & $\mathrm{R}$ & $\begin{array}{l}\text { Carp. orient. } \\
\& \text { merid. }\end{array}$ & mesohygrophyte & psichrothermophyte \\
\hline 103 & Hesperis oblongifolia Schur & - & - & - & - & $\mathrm{R}$ & $\begin{array}{l}\text { Carp. orient. } \\
\text { \& merid. }\end{array}$ & mesohygrophyte & hekistothermophyte \\
\hline 104 & $\begin{array}{l}\text { Hieracium rotundatum Kit. ex Schult. [syn. Hieracium } \\
\text { transsilvanicum] }\end{array}$ & - & - & - & - & - & $\begin{array}{l}\text { Carp.-Balc.- } \\
\text { Centr. Eur. }\end{array}$ & mesophyte & eurithermophyte \\
\hline 105 & $\begin{array}{l}\text { Hornungia alpina (L.) O.Appel subsp. brevicaulis (Spreng.) } \\
\text { O.Appel }\end{array}$ & - & - & - & - & $\mathrm{R}$ & Alp. Eur. & mesohygrophyte & eurithermophyte \\
\hline 106 & $\begin{array}{l}\text { Hypericum richeri Vill. subsp. transsilvanicum (Čelak.) } \\
\text { Ciocârlan }\end{array}$ & - & - & - & - & - & $\begin{array}{l}\text { Carp. orient. } \\
\& \text { merid. }\end{array}$ & $\begin{array}{l}\text { xeromesophyte - } \\
\text { mesophyte }\end{array}$ & microthermophyte - mesothermophyte \\
\hline 107 & Iris aphylla $\mathrm{L}$. & DD & $\mathrm{II} / \mathrm{IV}$ & - & - & - & Cont. Eur. & xeromesophyte & eurithermophyte \\
\hline 108 & $\begin{array}{l}\text { Jacobaea abrotanifolia (L.) Moench subsp. carpathica } \\
\text { (Herbich) B.Nord. \& Greuter [syn. Senecio carpathicus] }\end{array}$ & - & - & - & - & $\mathrm{R}$ & Carp.-Balc. & mesophyte & psichrothermophyte \\
\hline 109 & Juncus filiformis $\mathrm{L}$. & - & - & - & - & $\mathrm{R}$ & $\begin{array}{l}\text { Circ. arct.- } \\
\text { alp. }\end{array}$ & hygrophyte & microthermophyte - mesothermophyte \\
\hline
\end{tabular}


Sârbu Aet al. (2020). Not Bot Horti Agrobo 48(1):456-479.

\begin{tabular}{|c|c|c|c|c|c|c|c|c|c|}
\hline 110 & Loiseleuria procumbens (L.) Loisel. & - & - & - & - & $\mathrm{R}$ & $\begin{array}{l}\text { Circ. arct.- } \\
\text { alp. }\end{array}$ & $\begin{array}{l}\text { xeromesophyte - } \\
\text { mesophyte }\end{array}$ & psichrothermophyte \\
\hline 111 & Kobresia myosuroides (Vill.) Fiori & - & - & - & - & $\mathrm{R}$ & $\begin{array}{l}\text { Circ. arct.- } \\
\text { alp. }\end{array}$ & mesophyte & hekistothermophyte \\
\hline 112 & Kobresia simpliciuscula (Wahlenb.) Mack. & - & - & - & - & $\mathrm{R}$ & $\begin{array}{l}\text { Circ. bor.- } \\
\text { arct.-alp. }\end{array}$ & $\begin{array}{l}\text { xeromesophyte - } \\
\text { mesophyte }\end{array}$ & hekistothermophyte \\
\hline 113 & $\begin{array}{l}\text { Koeleria macrantha (Ledeb.) Schult. subsp. transsilvanica } \\
\text { (Schur) A.Nyár. }\end{array}$ & - & - & - & - & $\mathrm{R}$ & $\begin{array}{l}\text { Carp. } \\
\text { (Romania) }\end{array}$ & xeromesophyte & mesothermophyte \\
\hline 114 & Larix decidua Mill. var. carpatica Domin & - & - & - & - & $\mathrm{R}$ & Carp-Sudet. & mesophyte & microthermophyte - mesothermophyte \\
\hline 115 & Leontopodium alpinum Cass. & - & - & - & - & $\mathrm{V} / \mathrm{R}$ & Euras. alp. & $\begin{array}{l}\text { mesophyte - } \\
\text { mesohygrophyte }\end{array}$ & psichrothermophyte \\
\hline 116 & $\begin{array}{l}\text { Leucanthemum rotundifolium DC. [syn. Leucanthemum } \\
\text { waldsteinii] }\end{array}$ & - & - & - & - & $\mathrm{R}$ & $\begin{array}{ll}\text { Carp. } \quad \& \\
\text { Iugosl. } & \\
\text { Centr. } & \\
\end{array}$ & $\begin{array}{l}\text { mesophyte - } \\
\text { mesohygrophyte }\end{array}$ & microthermophyte \\
\hline 117 & Ligularia glauca (L.) O.Hoffm. & - & - & - & - & $\mathrm{R}$ & $\begin{array}{l}\text { Carp.-Balc.-S } \\
\text { Siberian }\end{array}$ & $\begin{array}{l}\text { mesophyte - } \\
\text { mesohygrophyte }\end{array}$ & microthermophyte \\
\hline 118 & Ligularia sibirica (L.) Cass. & DD & $\mathrm{II} / \mathrm{IV}$ & I & - & $\mathrm{R}$ & Euras. bor. & $\begin{array}{l}\text { mesohygrophyte } \\
\text { - hygrophyte }\end{array}$ & microthermophyte \\
\hline 119 & Ligusticum mutellinoides Vill. & - & - & - & - & $\mathrm{R}$ & $\begin{array}{l}\text { Euras. arct.- } \\
\text { alp. }\end{array}$ & mesophyte & hekistothermophyte - psichrothermophyte \\
\hline 120 & Linaria alpina (L.) Mill. & - & - & - & - & $\mathrm{R}$ & Eur. (alp.) & $\begin{array}{l}\text { xeromesophyte - } \\
\text { mesophyte }\end{array}$ & eurithermophyte \\
\hline 121 & Linum extraaxilare Kit. & - & - & - & - & nt & Carp.-Balc. & $\begin{array}{l}\text { xeromesophyte - } \\
\text { mesophyte }\end{array}$ & eurithermophyte \\
\hline 122 & Lloydia serotina (L.) Rchb. & - & - & - & - & $\mathrm{R}$ & $\begin{array}{l}\text { Circ. arct.- } \\
\text { alp. }\end{array}$ & $\begin{array}{l}\text { xeromesophyte - } \\
\text { mesophyte }\end{array}$ & eurithermophyte \\
\hline 123 & Lomatogonium carinthiacum (Wulfen) A.Braun & - & - & - & - & $\mathrm{R}$ & Circ.-alp. & xeromesophyte & psichrothermophyte \\
\hline 124 & Lonicera caerulea L. & - & - & - & - & $\mathrm{R}$ & $\begin{array}{l}\text { Circ. arct.- } \\
\text { alp. }\end{array}$ & $\begin{array}{l}\text { mesophyte - } \\
\text { mesohygrophyte }\end{array}$ & microthermophyte \\
\hline 125 & Lycopodium alpinum $\mathrm{L}$. & - & $\mathrm{V}$ & - & - & - & $\begin{array}{l}\text { Circ. arct.- } \\
\text { alp. }\end{array}$ & mesophyte & psichrothermophyte \\
\hline 126 & Monotropa hypopitys L. & - & - & - & - & $\mathrm{R}$ & Circ. & mesophyte & microthermophyte \\
\hline 127 & $\begin{array}{l}\text { Neotinea ustulata (L.) R.M.Bateman, Pridgeon \& } \\
\text { M.W.Chase [syn. Orchis ustulata] }\end{array}$ & LC & - & - & II & $\mathrm{R}$ & Eur. & mesophyte & mesothermophyte \\
\hline
\end{tabular}


Sârbu Aet al. (2020). Not Bot Horti Agrobo 48(1):456-479.

\begin{tabular}{|c|c|c|c|c|c|c|c|c|c|}
\hline 128 & $\begin{array}{l}\text { Neottia cordata (L.) Rich. } \\
{[\text { syn. Listera cordata }]}\end{array}$ & $\mathrm{LC}$ & - & - & II & $\mathrm{R}$ & Circ. & mesohygrophyte & eurithermophyte \\
\hline 129 & Neottia nidus-avis (L.) Rich. & LC & - & - & II & $\mathrm{R}$ & Euras. & mesophyte & mesothermophyte \\
\hline 130 & Neottia ovata (L.) Bluff \& Fingerh. [syn. Listera ovata] & $\mathrm{LC}$ & - & - & II & $\mathrm{R}$ & Euras. & $\begin{array}{l}\text { mesophyte - } \\
\text { mesohygrophyte }\end{array}$ & mesothermophyte \\
\hline 131 & $\begin{array}{l}\text { Onobrychis montana DC. subsp. transsilvanica (Simonk.) } \\
\text { Jáv. }\end{array}$ & - & - & - & - & $\mathrm{R}$ & $\begin{array}{l}\text { Carp. } \\
\text { (Romania) }\end{array}$ & xeromesophyte & psichrothermophyte \\
\hline 132 & Ophrys insectifera $\mathrm{L}$. & LC & - & - & II & $\mathrm{R}$ & Eur. & xeromesophyte & mesothermophyte \\
\hline 133 & Orchis mascula (L.) L. & LC & - & - & II & $\mathrm{R}$ & Submedit. & mesophyte & mesothermophyte \\
\hline 134 & Orchis militaris $\mathrm{L}$. & LC & - & - & II & $\mathrm{R}$ & Euras. & mesophyte & mesothermophyte \\
\hline 135 & Oxyria digyna (L.) Hill & - & - & - & - & $\mathrm{R}$ & $\begin{array}{l}\text { Circ. } \text { arct.- } \\
\text { alp. }\end{array}$ & mesohygrophyte & hekistothermophyte \\
\hline 136 & Oxytropis carpathica R.Uechtr. & - & - & - & - & $\mathrm{R}$ & Carp. & $\begin{array}{l}\text { xeromesophyte - } \\
\text { mesophyte }\end{array}$ & psichrothermophyte \\
\hline 137 & Oxytropis halleri Koch & - & - & - & - & $\mathrm{R}$ & Alp. eur. & xeromesophyte & psichrothermophyte \\
\hline 138 & $\begin{array}{l}\text { Papaver alpinum L. subsp. corona-sancti-stephani (Zapal.) } \\
\text { Borza }\end{array}$ & - & - & - & - & $\mathrm{R}$ & $\begin{array}{l}\text { Carp. orient. } \\
\& \text { merid. }\end{array}$ & xeromesophyte & microthermophyte \\
\hline 139 & Phyteuma confusum A.Kern. & - & - & - & - & $\mathrm{R}$ & $\begin{array}{l}\text { Alp.-Carp.- } \\
\text { Balc. }\end{array}$ & mesophyte & microthermophyte \\
\hline 140 & Phyteuma vagneri A.Kern. & - & - & - & - & $\mathrm{R}$ & Carp. & mesophyte & psichrothermophyte \\
\hline 141 & Pinguicula alpina $\mathrm{L}$. & - & - & - & - & $\mathrm{R}$ & $\begin{array}{l}\text { Euras. arct.- } \\
\text { alp. }\end{array}$ & $\begin{array}{l}\text { mesohygrophyte } \\
\text { - hygrophyte }\end{array}$ & eurithermophyte \\
\hline 142 & Pinguicula vulgaris $\mathrm{L}$. & $\mathrm{LC}$ & - & - & - & $\mathrm{R}$ & Circ. & $\begin{array}{l}\text { mesohygrophyte } \\
\text { - hygrophyte }\end{array}$ & eurithermophyte \\
\hline 143 & Pinus cembra $\mathrm{L}$. & - & - & - & - & $\mathrm{R}$ & $\begin{array}{l}\text { Euras. arct.- } \\
\text { alp. }\end{array}$ & mesophyte & psichrothermophyte - microthermophyte \\
\hline 144 & Plantago atrata Hoppe subsp. carpatica (Pilg.) Soó & - & - & - & - & $\mathrm{R}$ & Carp. & $\begin{array}{l}\text { mesophyte - } \\
\text { mesohygrophyte }\end{array}$ & microthermophyte \\
\hline 145 & Plantago gentianoides $\mathrm{Sm}$. & - & - & - & - & $\mathrm{R}$ & $\begin{array}{l}\text { Carp.-Balc.- } \\
\text { Anat. }\end{array}$ & mesohygrophyte & microthermophyte \\
\hline 146 & Platanthera bifolia (L.) Rich. & $\mathrm{LC}$ & - & - & II & $\mathrm{R}$ & Euras. & $\begin{array}{l}\text { mesophyte - } \\
\text { mesohygrophyte }\end{array}$ & eurithermophyte \\
\hline 147 & Platanthera clorantha (Custer) Rchb. & LC & - & - & II & $\mathrm{R}$ & Euras. & mesophyte & mesothermophyte \\
\hline
\end{tabular}


Sârbu A et al. (2020). Not Bot Horti Agrobo 48(1):456-479.

\begin{tabular}{|c|c|c|c|c|c|c|c|c|c|}
\hline 148 & Pleurospermum austriacum (L.) Hoffm. & - & - & - & - & $\mathrm{R}$ & $\begin{array}{l}\text { Eur. Centr. } \\
\text { (mont.) }\end{array}$ & mesohygrophyte & microthermophyte \\
\hline 149 & Poa molineri Balb. subsp. glacialis Beldie & - & - & - & - & $\mathrm{R}$ & Bucegi & xeromesophyte & microthermophyte \\
\hline 150 & Poa remota Forselles & - & - & - & - & $\mathrm{R}$ & Euras. bor. & $\begin{array}{l}\text { mesophyte - } \\
\text { mesohygrophyte }\end{array}$ & microthermophyte - mesothermophyte \\
\hline 151 & Polemonium caeruleum $\mathrm{L}$. & - & - & - & - & $\mathrm{R}$ & Circ. & mesohygrophyte & microthermophyte - mesothermophyte \\
\hline 152 & Potentilla palustris (L.) Scop. & - & - & - & - & $\mathrm{R}$ & Circ. bor. & hygrophyte & microthermophyte \\
\hline 153 & Primula halleri J.F.Gmel. & - & - & - & - & $\mathrm{R}$ & Alp. Eur. & mesophyte & microthermophyte \\
\hline 154 & Pseudorchis albida (L.) Á.Löve \& D.Löve & LC & - & - & II & $\mathrm{R}$ & Eur. (mont.) & mesophyte & microthermophyte \\
\hline 155 & Pulmonaria rubra Schott & - & - & - & - & - & Carp.-Balc. & mesophyte & microthermophyte \\
\hline 156 & Pyrola carpatica Holub \& Kř́sa & - & - & - & - & $\mathrm{R}$ & Carp. & mesophyte & microthermophyte - mesothermophyte \\
\hline 157 & Ranunculus carpaticus Herbich & - & - & - & - & $\mathrm{R}$ & Dacic & mesohygrophyte & microthermophyte \\
\hline 158 & Ranunculus thora $\mathrm{L}$. & - & - & - & - & $\mathrm{R}$ & $\begin{array}{l}\text { Pirin.alp.- } \\
\text { Apen.-W } \\
\text { Balc.-Carp. }\end{array}$ & mesohygrophyte & hekistothermophyte \\
\hline 159 & Rhododendron myrtifolium Schott \& Kotschy & - & - & - & - & $\mathrm{V}$ & Carp.-Balc. & mesophyte & eurithermophyte \\
\hline 160 & Salix alpina Scop. & - & - & - & - & $\mathrm{R}$ & Alp.-Carp. & mesohygrophyte & hekistothermophyte - psichrothermophyte \\
\hline 161 & Salix bicolor Ehrh. ex Willd. & - & - & - & - & $\mathrm{R}$ & $\begin{array}{l}\text { Alp.- } \\
\text { W\&Centr. } \\
\text { Eur. }\end{array}$ & mesohygrophyte & hekistothermophyte - psichrothermophyte \\
\hline 162 & Salix daphnoides Vill. & - & - & - & - & $\mathrm{R}$ & Centr. Eur. & $\begin{array}{l}\text { mesohygrophyte } \\
\text { - hygrophyte }\end{array}$ & microthermophyte \\
\hline 163 & Salix retusa $\mathrm{L}$. & - & - & - & - & $\mathrm{R}$ & Alp. Eur. & $\begin{array}{l}\text { mesophyte - } \\
\text { mesohygrophyte }\end{array}$ & psichrothermophyte \\
\hline 164 & Saussurea alpina (L.) DC. & - & - & - & - & $\mathrm{R}$ & $\begin{array}{l}\text { Circ. arct.- } \\
\text { alp. }\end{array}$ & mesophyte & hekistothermophyte \\
\hline 165 & Saussurea discolor (Willd.) DC. & - & - & - & - & $\mathrm{R}$ & $\begin{array}{l}\text { Alps, Carp. } \\
\text { Apennine }\end{array}$ & mesophyte & hekistothermophyte \\
\hline
\end{tabular}


Sârbu A et al. (2020). Not Bot Horti Agrobo 48(1):456-479.

\begin{tabular}{|c|c|c|c|c|c|c|c|c|c|}
\hline 166 & Saxifraga carpatica Sternb. & - & - & - & - & $\mathrm{R}$ & Carp--Balc. & $\begin{array}{l}\text { mesophyte - } \\
\text { mesohygrophyte }\end{array}$ & psichrothermophyte \\
\hline 167 & Saxifraga cernua $\mathrm{L}$. & - & - & - & - & $\mathrm{R}$ & $\begin{array}{l}\text { Circ. arct.- } \\
\text { alp. }\end{array}$ & $\begin{array}{l}\text { mesohygrophyte } \\
\text { - hygrophyte }\end{array}$ & hekistothermophyte \\
\hline 168 & $\begin{array}{l}\text { Saxifraga mutata L. subsp. demissa (Schott \& Kotschy) } \\
\text { D.A.Webb [syn. Saxifraga demissa] }\end{array}$ & - & - & - & - & $\mathrm{V} / \mathrm{R}$ & Carp. merid. & $\begin{array}{l}\text { xerophyte } \\
\text { xeromesophyte }\end{array}$ & psichrothermophyte \\
\hline 169 & Saxifraga oppositifolia $\mathrm{L}$. & - & - & - & - & $\mathrm{R}$ & $\begin{array}{l}\text { Circ. arct.- } \\
\text { alp. }\end{array}$ & $\begin{array}{l}\text { mesophyte - } \\
\text { mesohygrophyte }\end{array}$ & psichrothermophyte \\
\hline 170 & Saxifraga retusa Gouan & - & - & - & - & $\mathrm{R}$ & Alp. Eur. & xeromesophyte & hekistothermophyte \\
\hline 171 & Scabiosa lucida Vill. subsp. barbata Nyár. & - & - & - & - & $\mathrm{R}$ & $\begin{array}{l}\text { Carp. } \\
\text { (Romania) }\end{array}$ & mesophyte & microthermophyte \\
\hline 172 & $\begin{array}{l}\text { Scorzoneroides pseudotaraxaci (Schur) Holub }[\text { syn. } \\
\text { Leontodon montanus subsp. pseudotaraxaci }]\end{array}$ & - & - & - & - & $\mathrm{R}$ & Carp. & mesophyte & psichrothermophyte \\
\hline 173 & Secale montanum $\mathrm{L}$. & - & - & - & - & $\mathrm{R}$ & Medit. & $\begin{array}{l}\text { xeromesophyte - } \\
\text { mesophyte }\end{array}$ & subthermophyte \\
\hline 174 & Sedum grisebachii Boiss. \& Heldr. & - & - & - & - & $\mathrm{R}$ & Carp.-Balc. & mesophyte & mesothermophyte \\
\hline 175 & Sesleria bielzii Schur & - & - & - & - & $\mathrm{R}$ & Carp.-Balc. & mesophyte & psichrothermophyte \\
\hline 176 & Sesleria rigida Heuff. ex Rchb. [syn. Sesleria haynaldiana] & - & - & - & - & - & Carp.-Balc. & $\begin{array}{l}\text { xeromesophyte - } \\
\text { mesophyte }\end{array}$ & subthermophyte \\
\hline 177 & Silene nutans L. subsp. dubia (Herbich) Zapal. & - & - & - & - & $\mathrm{R}$ & $\begin{array}{l}\text { Carp. } \\
\text { (Romania) }\end{array}$ & xeromesophyte & mesothermophyte \\
\hline 178 & Soldanella pusilla Baumg. & - & - & - & - & $\mathrm{R}$ & Carp.-Balc. & mesohygrophyte & microthermophyte \\
\hline 179 & Streptopus amplexifolius (L.) DC. & - & - & - & - & $\mathrm{R}$ & Circ. & mesohygrophyte & microthermophyte \\
\hline 180 & Symphytum cordatum Waldst. \& Kit ex Willd. & - & - & - & - & - & Carp. & mesohygrophyte & microthermophyte \\
\hline 181 & Taraxacum fontanum Hand.-Mazz. & - & - & - & - & $\mathrm{R}$ & Euras. alp. & mesohygrophyte & psichrothermophyte \\
\hline 182 & Taxus baccata $\mathrm{L}$. & - & - & - & - & $\mathrm{V} / \mathrm{R}$ & $\begin{array}{l}\text { Atl.-Medit.- } \\
\text { Centr. Eur. }\end{array}$ & mesophyte & mesothermophyte - submesothermophyte \\
\hline 183 & Tephroserispapposa (Rchb.) Schur [syn. Senecio papposus] & - & - & - & - & - & Carp--Balc. & mesophyte & microthermophyte \\
\hline 184 & Thalictrum alpinum $\mathrm{L}$. & - & - & - & - & $\mathrm{R}$ & $\begin{array}{l}\text { Circ. bor-- } \\
\text { arct.-alp. }\end{array}$ & mesophyte & microthermophyte \\
\hline
\end{tabular}


Sârbu Aet al. (2020). Not Bot Horti Agrobo 48(1):456-479.

\begin{tabular}{|c|c|c|c|c|c|c|c|c|c|}
\hline 185 & Thesium kernerianum Simonk. & - & - & - & - & $\mathrm{R}$ & Dacic & xeromesophyte & hekistothermophyte \\
\hline 186 & Thlaspi dacicum Heuff. s.l. & - & - & - & - & $\mathrm{R}$ & Carp. & xeromesophyte & psichrothermophyte \\
\hline 187 & Thymus bihoriensis Jalas [syn. Thymus marginatus] & - & - & - & - & - & Carp. & $\begin{array}{l}\text { xeromesophyte - } \\
\text { mesophyte }\end{array}$ & microthermophyte \\
\hline 188 & Thymus comosus Heuff. ex Griseb. \& Schenk & - & - & - & - & nt & Carp. & xeromesophyte & microthermophyte - mesothermophyte \\
\hline 189 & Thymus pulcherrimus Schur & - & - & - & - & $\mathrm{R}$ & Carp. & xeromesophyte & psichrothermophyte \\
\hline 190 & Tozzia carpatbica Woloszack & $\mathrm{DD}$ & $\mathrm{II} / \mathrm{IV}$ & - & - & $\mathrm{R}$ & Carp-Balc. & mesohygrophyte & microthermophyte \\
\hline 191 & Traunsteinera globosa (L.) Rchb. & LC & - & - & - & $\mathrm{R}$ & $\begin{array}{l}\text { Centr. Eur. } \\
\text { (mont.) }\end{array}$ & mesophyte & microthermophyte \\
\hline 192 & Trisetum alpestre (Host) P.Beauv. & - & - & - & - & $\mathrm{R}$ & Alp.-Carp. & mesophyte & microthermophyte \\
\hline 193 & Trisetum macrotrichum Hack. & - & - & - & - & $\mathrm{R}$ & Carp. & mesophyte & microthermophyte - mesothermophyte \\
\hline 194 & Trollius europaeus L. s.l. & - & - & - & - & $\mathrm{R}$ & Eur. & mesohygrophyte & microthermophyte \\
\hline 195 & Vaccinium uliginosum $\mathrm{L}$. & - & - & - & - & $\mathrm{R}$ & Circ. bor. & $\begin{array}{l}\text { xeromesophyte - } \\
\text { mesophyte }\end{array}$ & psichrothermophyte \\
\hline 196 & Veronica alpina $\mathrm{L}$. & - & - & - & - & $\mathrm{R}$ & $\begin{array}{l}\text { Circ. arct.- } \\
\text { alp. }\end{array}$ & mesohygrophyte & hekistothermophyte \\
\hline 197 & Veronica aphylla $\mathrm{L}$. & - & - & - & - & $\mathrm{R}$ & Alp. Eur. & $\begin{array}{l}\text { mesophyte } \\
\text { mesohygrophyte }\end{array}$ & psichrothermophyte \\
\hline 198 & Veronica baumgartenii Roem. \& Schult. & - & - & - & - & $\mathrm{R}$ & Carp. & $\begin{array}{l}\text { mesophyte - } \\
\text { mesohygrophyte }\end{array}$ & psichrothermophyte \\
\hline 199 & Viola alpina Jacq. & - & - & - & - & $\mathrm{R}$ & Alp.-Carp. & xeromesophyte & psichrothermophyte - microthermophyte \\
\hline 200 & Viola dacica Borbás & - & - & - & - & $\mathrm{R}$ & Carp.-balc. & mesophyte & microthermophyte \\
\hline
\end{tabular}

